\title{
Optimization Conditions of the Preparation of Activated Carbon Based Egusi (Cucumeropsis mannii Naudin) Seed Shells for Nitrate Ions Removal from Wastewater
}

\author{
René Blaise Ngouateu Lékéné1,2, Julius Ndi Nsami1 ${ }^{*}$, Asma Rauf², \\ Daouda Kouotou' ${ }^{1}$, Placide Desiré Belibi Belibi1, \\ Muhammad Iqbal Bhanger ${ }^{2}$, Joseph Ketcha Mbadcam1 \\ ${ }^{1}$ Applied Physical and Analytical Chemistry Laboratory, Department of Inorganic Chemistry, Faculty of Science, University of \\ Yaoundé I, Yaoundé, Cameroon \\ ${ }^{2}$ H.E.J. Research Institute of Chemistry, University of Karachi, Karachi, Pakistan \\ Email: *bigpielo2002@yahoo.com
}

How to cite this paper: Lékéné, R.B.N., Nsami, J.N., Rauf, A., Kouotou, D., Belibi, P.D.B., Bhanger, M.I. and Mbadcam, J.K. (2018) Optimization Conditions of the Preparation of Activated Carbon Based Egusi (Cucumeropsis mannii Naudin) Seed Shells for Nitrate Ions Removal from Wastewater. American Journal of Analytical Chemistry, 9 , 439-463.

https://doi.org/10.4236/ajac.2018.910034

Received: May 29, 2018

Accepted: October 7, 2018

Published: October 10, 2018

Copyright (ㅇ 2018 by authors and Scientific Research Publishing Inc. This work is licensed under the Creative Commons Attribution International License (CC BY 4.0).

http://creativecommons.org/licenses/by/4.0/

\section{(c) (i) Open Access}

\begin{abstract}
Egusi seed shells (ESS) were used as precursor for the preparation of two activated carbons (ACs) following $\mathrm{H}_{3} \mathrm{PO}_{4}$ and $\mathrm{ZnCl}_{2}$ activation. The effect of factors controlling the preparation of ACs such as chemical activating agent concentration $(2-10 \mathrm{M})$, activation temperature $\left(400^{\circ} \mathrm{C}-700^{\circ} \mathrm{C}\right)$ and residence time (30 - $120 \mathrm{~min}$ ) were optimized using the Box-Behnken Design (BBD). The optimized activated carbons based $\mathrm{H}_{3} \mathrm{PO}_{4}$ (ACP) and $\mathrm{ZnCl}_{2}$ (ACZ) were characterized by $\mathrm{N}_{2}$ adsorption, elemental analysis, atomic force microscopy (AFM), Boehm titration and Fourier transformed infrared (FTIR) techniques. The specific surface area was found to be 1053.91 and $1009.89 \mathrm{~m}^{2} \cdot \mathrm{g}^{-1}$ for ACP and ACZ respectively. The adsorbents had similar surface functionalities and were both microporous. The effect of various parameters such as initial $\mathrm{pH}$, concentration, and contact time on the adsorption of nitrate ions on ACP and ACZ in aqueous solution was studied. ACZ demonstrated better adsorption capacity $\left(8.26 \mathrm{mg} \cdot \mathrm{g}^{-1}\right)$ compared to ACP $\left(5.65 \mathrm{mg} \cdot \mathrm{g}^{-1}\right)$ at the same equilibrium time of $20 \mathrm{~min}$. The adsorption process was governed by a "physical interactions" phenomenon for both adsorbents.
\end{abstract}

\section{Keywords}

Egusi Seed Shells, Activated Carbon, Optimization, Nitrate Ions, Wastewater, Adsorption Process 


\section{Introduction}

The main source of contamination of surface and ground water by nitrate ions is the excessive use of nitrogen fertilizers in agriculture. And the untreated waste water, released from industrial and municipal sites. This increases in disposal of nitrates in the environmental causes, eutrophication of water bodies which stimulates the rapid growth of algae and aquatic plants and consequently, affects fish and other aquatic life negatively [1] [2]. The consumption of nitrate contaminated water causes health problems to humans such as methemoglobinemia in infant or baby-blue syndrome and stomach cancer in adults [1] [3]. As a result, the World Health Organization (WHO) has fixed a maximum acceptable concentration of nitrate ions in drinking water to be $50 \mathrm{mg} \cdot \mathrm{L}^{-1}$ [4].

Among the methods used for the removal of nitrate ions from waste and drinking water, adsorption has been shown to be the better economical and efficient alternative [5]. To this end, several adsorbents including chitosan, agricultural residue, MCM-48, SBA-15, volcanic pumice and carbon-based adsorbents have been tested [2] [6] [7]. The large surface area of activated carbons (500 $\left.2000 \mathrm{~m}^{2} \cdot \mathrm{g}^{-1}\right)$ is responsible for their wide application as adsorbents in water treatment. The recent focus has been the use of low cost precursors from agricultural (biomass) and industrial waste as precursors to prepare activated carbons [8] [9] [10] [11]. Examples include date stone [12], oil palm shell [13], sewage sludge [14], Fox nut shell [15], cola nut shell [16], cherry stone [17], tomato processing waste [18] crab shell [19], bamboo [20], and coconut shell [21].

Physical, chemical and physicochemical activation are the three common methods used for production of ACs. Physical activation involves two steps: carbonization and activation at high temperature $\left(600^{\circ} \mathrm{C}-1200^{\circ} \mathrm{C}\right)$ in presence of activating agents such as steam and/or $\mathrm{CO}_{2}$ [8] [22]. Chemical activation is performed in single step, by impregnating the precursor with oxidizing reagents such as $\mathrm{KOH}, \mathrm{ZnCl}_{2}, \mathrm{H}_{3} \mathrm{PO}_{4}$, or $\mathrm{K}_{2} \mathrm{HPO}_{4}$ and carbonizing at a lower temperature range $\left(400^{\circ} \mathrm{C}-700^{\circ} \mathrm{C}\right)$, followed by extensively washing to remove excess activating agent [8] [10] [20]. Physicochemical activation is a combination of physical and chemical activation [13] [22]. Chemical activation is mostly used because of good yield, and it utilizes less energy and time [19] [23].

Egusi (Cucumeropsis mannii Naudin) is an herbaceous annual plant belonging to the large family of Cucurbitaceae. It is cultivated for seed which is commonly used in food as condiment and thickener (in soup) in Nigeria, Cameroon, Ghana, Middle East, Uganda and other African countries [24] [25] [26]. Recently, Giwa et al. [24], show that the oil extract from Egusi seeds could be used as potential feedstock for biodiesel production. To our knowledge, no such study has been done regarding use of Egusi seed shells as a starting material for the preparation of ACs.

In the preparation of ACs by chemical activation, several factors including the carbonization temperature, residential time, impregnation ratio, heating rate influences the properties of the obtained AC. Such multivariate systems, require 
numerous trials to thoroughly investigate the factors which control the system [27] [28]. Response Surface Methodology (RSM) is a useful tool; it reduces the number of experimental trials, evaluates the interaction between the studied factors and provide the optimal operating conditions [27] [29] [30].

In present work, we use the Box-Behnken Design (BBD) to optimize the preparation conditions of ACs from ESS by chemical activation using two activating agents $\left(\mathrm{ZnCl}_{2}\right.$ and $\left.\mathrm{H}_{3} \mathrm{PO}_{4}\right)$. The optimized ACs were characterized to determine their specific surface area $\left(\mathrm{N}_{2}\right.$ adsorption), surface morphology (Atomic Force Microscopy), elemental analysis, major functional groups (FT-IR spectroscopy and Boehm titration), $\mathrm{pH}$ of point of zero charge $\left(\mathrm{pH}_{\mathrm{PZC}}\right)$, and used as adsorbent for the removal of nitrate ions from aqueous solution.

\section{Experimental}

\subsection{Preparation of Activated Carbons}

The Egusi Seed Shells (ESS) were collected from Mokolo, a local market in the Centre Region of Cameroon. They were washed with deionized water and dried for $24 \mathrm{~h}$ at $105^{\circ} \mathrm{C}$. The dried ESS were ground and sieved to $1-1.25 \mathrm{~mm}$ sizes. Impregnation was carried out by adding $50 \mathrm{~mL}$ of $\mathrm{ZnCl}_{2}$ or $\mathrm{H}_{3} \mathrm{PO}_{4}(2-10 \mathrm{M})$ to $10.0 \mathrm{~g}$ of ESS and stirred constantly for $12 \mathrm{~h}$ at room temperature $\left(27^{\circ} \mathrm{C}\right)$, to ensure completion of reaction between activating agent and ESS particles. This mixture was filtered and the residue was dried in an oven at $105^{\circ} \mathrm{C}$ for $24 \mathrm{~h} \mathrm{[8]}$ [31]. The impregnated ESS were carbonized in a muffle furnace (Carbolite Furnaces) at required temperature $\left(400^{\circ} \mathrm{C}-700^{\circ} \mathrm{C}\right)$, residence time $(30-120 \mathrm{~min})$ and at constant heating rate of $5^{\circ} \mathrm{C} / \mathrm{min}$ in the absence of oxygen and under self-generated atmosphere. After carbonization, the samples were allowed to cool down to room temperature. The obtained ACs were washed with deionized water repeatedly until the $\mathrm{pH}$ of supernatant became neutral and oven dried at $105^{\circ} \mathrm{C}$ for $24 \mathrm{~h}$. The samples were then crushed and sieved with an $80 \mu \mathrm{m} \mathrm{di}-$ ameter mesh sieve and stored in plastic containers. The ACs were labeled as $\mathrm{ACZ}$ and ACP for ESS activated with $\mathrm{ZnCl}_{2}$ and $\mathrm{H}_{3} \mathrm{PO}_{4}$, respectively.

\subsection{Response Surface Optimization of ACs Production}

\subsubsection{Iodine Number (IN)}

The iodine adsorption test is employed to determine the adsorption capacity of $\mathrm{AC}$, and $\mathrm{IN}$ value is used to determine if an $\mathrm{AC}$ is microporous $(0-2 \mathrm{~nm})$. IN value is obtained as the quantity of Iodine $\left(\mathrm{I}_{2}\right)$ adsorbed per gram of AC on a milligram scale. The IN for all samples were obtained following ASTM D4907 94 method [10] [20].

\subsubsection{Methylene Blue Number (MBN)}

The MBN is a measure of the mesoporosity $(2-50 \mathrm{~nm})$ of an $\mathrm{AC}$, and is obtained as the amount of dye adsorbed on $1 \mathrm{~g}$ of adsorbent [10]. The MBN test was performed by mixing $0.020 \mathrm{~g}$ of $\mathrm{AC}$ and $10 \mathrm{~mL}$ of $1000 \mathrm{mg} \cdot \mathrm{g}^{-1} \mathrm{MB}$ solution and stirring the solution for $24 \mathrm{~h}$ in order to achieve equilibrium state [32]. The 
concentration of $\mathrm{MB}$ was measured at $660 \mathrm{~nm}$ using a double beam UV-visible spectrophotometer (Thermo Scientific Evolution 300, USA).

\subsubsection{Activated Carbon Yield}

The activated carbon yield was calculated as the dry weight of obtained AC to raw material according to Equation (1),

$$
\operatorname{Yield}(\%)=\frac{m_{A C}}{m_{0}} \times 100
$$

where $m_{A C}$ and $m_{0}$ are dried mass of $\mathrm{AC}$ and the dried mass of raw material respectively.

\subsection{Experimental Design and Statistical Analysis}

The ACs preparation was studied using the Box-Behnken Design (BBD). BBD reduces the number of experiments with no loss of accuracy and estimates complex response functions more effectively, compared to other design [30] [33] [34]. Generally, the number of experimental runs is estimated by Equation (2)

$$
N=k^{2}+k+C_{p}=3^{2}+3+3=15
$$

where $k$ and $C_{p}$ are the number of variables studied and the number of central points (replicates) respectively [35].

The three variables studied are the concentration of activating agent $\left(\mathrm{H}_{3} \mathrm{PO}_{4}\right.$ or $\left.\mathrm{ZnCl}_{2}\right)\left(x_{1}\right)$, carbonization temperature $\left(x_{2}\right)$ and residence time $\left(x_{3}\right)$. These variables were chosen based on preliminary studies. The effect of the variables (i.e. $\left.X_{1}, X_{2}, x_{3}\right)$ on IN, MBN values and product yield was evaluated using a second order polynomial equation as given by Equation (3) [36].

$$
Y=a_{0}+\sum_{i=1}^{k} a_{i} x_{i}+\sum_{i=1}^{k} a_{i i} x_{i}^{2}+\sum_{i=1}^{k} \sum_{j=1}^{k} a_{i j} x_{i} x_{j}+\varepsilon
$$

where, $Y$ is the response obtained, $a_{0}$ is a constant, $a_{i}$ slope or linear effect of the input factor $x_{i}, a_{i p}$ defines a linear interaction between factors $x_{i}$ and $x_{j}, a_{i i}$ is the quadratic effect of factor $x_{i}$ and $\varepsilon$ is the random error or represent uncertainties between predicted and measured values.

Minitab16 statistical software (Minitab 16 Inc.) was used for regression analysis of experimental data, to fit the second order polynomials equations and for the evaluation of the statistical significance of the developed equations (Equation (3)). The response surface plots were generated using SigmaPlot 11 software (Systat. Software, Inc.) to study the relationship between the factors and the responses.

\subsection{Characterization of ESS and ACs Prepared at Optimized Conditions}

The characterization of the raw material and optimized ACs was done following several analytical techniques. $\mathrm{N}_{2}$ adsorption experiments were carried out at $-196^{\circ} \mathrm{C}$ using a NovaWin Quantachrome instrument and the surface area and porosity determined respectively via Multipoint BET and Dubinin-Astakhov 
(DA) method. An Atomic Force Microscope (Agilent 5500 Technologies, Germany) was used to study the surface morphology. Elemental analysis (C, $\mathrm{H}$, and N) of ACs and ESS was performed on a Perkin Elmer Series II 2400 analyzer. The surface functional groups of ACs was determined by both Boehm titration method [37] and FT-IR spectroscopy (Brucker Vector-22, Germany) using $\mathrm{KBr}$ pellets in transmission mode within the $400-4000 \mathrm{~cm}^{-1}$ range. The $\mathrm{pH}$ of point of zero charge $\left(\mathrm{pH}_{\mathrm{PZC}}\right)$ was determined by the drift method [2].

\subsection{Adsorption Studies of Nitrate Ions}

Adsorption studies were conducted in order to investigate the effects of $\mathrm{pH}$, adsorbate concentration and contact time on the adsorption of $\mathrm{NO}_{3}^{-}$on ACP and ACZ. All experiments were performed repeatedly to get statistical value.

For equilibrium adsorption studies, a set of Erlenmeyer flasks containing 100 $\mathrm{mL} \mathrm{NO}_{3}^{-}$solution in the concentration range of 20 to $200 \mathrm{mg} \cdot \mathrm{L}^{-1}$ and $0.1 \mathrm{~g}$ of adsorbent (ACP or ACZ), were shaken at fixed speed of $150 \mathrm{rpm}$ for 1 hour at room temperature $\left(27^{\circ} \mathrm{C} \pm 2^{\circ} \mathrm{C}\right)$. The solution was filtered through a Whatman $\mathrm{N}^{\circ} 4$ filter paper and the amount of nitrate was estimated according to rapid colorimetric determination by the nitration of salicylic acid as reported by Cataldo et al. (1975) [38]. The adsorbed quantity at equilibrium $q_{e}\left(\mathrm{mg} \cdot \mathrm{g}^{-1}\right)$ was calculated from Equation (4)

$$
q_{e}=\frac{C_{0}-C_{e}}{m} \times V
$$

where, $C_{0}$ and $C_{e}\left(\mathrm{mg} \cdot \mathrm{L}^{-1}\right)$ are the concentration of $\mathrm{NO}_{3}^{-}$at initial and equilibrium state respectively; $V(\mathrm{~L})$ is the volume of solution; and $m(\mathrm{~g})$ the mass of the dry adsorbent. Three isotherm models, Freundlich, Langmuir and Dubinin-Radushkevich (D-R) were used to study the nitrate ions adsorption on ACP and ACZ. The non-linear form of these isotherm models is given in Table 1.

The effect of $\mathrm{pH}(3-11)$ on the adsorption of $\mathrm{NO}_{3}^{-}$by both ACP and ACZ was conducted using $\mathrm{pH}$ meter (Insmark, model IS 128). $\mathrm{pH}$ of solution was adjusted by adding $0.1 \mathrm{M} \mathrm{NaOH}$ or $0.1 \mathrm{M} \mathrm{HCl}$ solutions. The concentration of $\mathrm{NO}_{3}^{-}$and adsorbent (ACP and $\mathrm{ACZ}$ ) dose used were $50 \mathrm{mg} \cdot \mathrm{L}^{-1}$ and $0.1 \mathrm{~g}$, respectively.

For kinetics studies, batch adsorption experiments were carried out by stirring $0.1 \mathrm{~g}$ of adsorbent (ACP and ACP) and $100 \mathrm{ml}$ of $\mathrm{NO}_{3}^{-}$solution $\left(50 \mathrm{mg} \cdot \mathrm{L}^{-1}\right)$. The residual concentration of $\mathrm{NO}_{3}^{-}$in solution was determined at different time interval in range of 5 - 90 min. The quantity of $\mathrm{NO}_{3}^{-}$adsorbed was calculated by the following Equation (5)

$$
q_{t}=\frac{C_{0}-C_{t}}{m} \times V
$$

where, $C_{0}$ and $C_{t}\left(\mathrm{mg} \cdot \mathrm{L}^{-1}\right)$ are the initial and at time $t$ concentration of $\mathrm{NO}_{3}^{-}$. The kinetic models: pseudo-first-order, pseudo-second-order and intraparticle diffusion is given in Table 1. 
Table 1. Different isotherm and kinetic models.

\begin{tabular}{|c|c|c|}
\hline & Non-linear equation & Parameters \\
\hline Freundlich & $q_{e}=K_{F} C_{e}^{1 / n}$ & 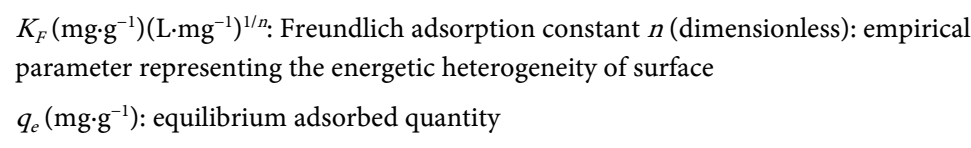 \\
\hline Langmuir & $q_{e}=\frac{q_{m} K_{L} C_{e}}{1+K_{L} C_{e}}$ & $\begin{array}{l}q_{m}\left(\mathrm{mg} \cdot \mathrm{g}^{-1}\right): \text { monolayer adsorption capacity } \\
C_{e}\left(\mathrm{mg} \cdot \mathrm{L}^{-1}\right): \text { equilibrium concentration } \\
K_{L}\left(\mathrm{~L} \cdot \mathrm{mg}^{-1}\right): \text { equilibium adsorption constant }\end{array}$ \\
\hline Dubinin-Radushkevich & $q_{e}=q_{s} \exp \left(-k_{a d}\left[R T \ln \left(1+\frac{1}{C_{e}}\right.\right.\right.$ & $\begin{array}{l}q_{s} \text { maximum adsorbed amount } \\
R\left(8.314 \mathrm{~J} \cdot \mathrm{mol}^{-1} \mathrm{~K}^{-1}\right) \text { : gas constant } \\
T(\mathrm{~K}) \text { : temperature }\end{array}$ \\
\hline Pseudo-first-order & $q_{t}=q_{e}\left[1-\exp \left(-k_{1} t\right)\right]$ & $\begin{array}{l}q_{t}\left(\mathrm{mg} \cdot \mathrm{g}^{-1}\right): \text { adsorbed quantity at time } \mathrm{t} \\
t(\mathrm{~min}): \text { contact time } \\
k_{1}\left(\mathrm{~min}^{-1}\right): \text { pseudo-fist order rate constant }\end{array}$ \\
\hline Pseudo-second-order & $q_{t}=\frac{q_{e}^{2} k_{2} t}{1+q_{e} k_{2} t}$ & $k_{2}\left(\mathrm{~g} \cdot \mathrm{mg}^{-1} \cdot \mathrm{min}^{-1}\right):$ pseudo-fist order rate constant \\
\hline $\begin{array}{l}\text { Intraparticular } \\
\text { diffusion }\end{array}$ & $q_{t}=k_{i p} t^{2}+C_{i}$ & $\begin{array}{l}K_{i p}\left(\mathrm{mg}^{-\mathrm{g}^{-1}} \cdot \mathrm{min}^{1 / 2}\right): \text { intraparticle diffusion rate constant } \\
C_{i:} \text { constant value depicting the boundary layer effect }\end{array}$ \\
\hline
\end{tabular}

In this study, non-linear regression was applied using Microsoft Excel Solver function. The best fit for experimental data was determined from the correlation coefficient $\left(R^{2}\right)$, residual root mean square error $(R M S E)$ and Chi-square test $\left(\chi^{2}\right)$, which are defined by Equations (6)-(8) respectively [6],

$$
\begin{gathered}
R^{2}=1-\frac{\sum_{n=1}^{n}\left(q_{e . e x p, n}-q_{e . p r e, n}\right)^{2}}{\sum_{n=1}^{n}\left(q_{e . e x p, n}-\overline{q_{e . e x p, n}}\right)^{2}} \\
R M S E=\sqrt{\frac{\sum_{n=1}^{n}\left(q_{e . e x p, n}-q_{e . p r e, n}\right)^{2}}{n-1}} \\
\chi^{2}=\sum_{n=1}^{n} \frac{\left(q_{e . e x p, n}-q_{e . p r e, n}\right)^{2}}{q_{e . e x p, n}}
\end{gathered}
$$

where, $q_{e . e x p}$ and $q_{e . p r e}$ are experimental and predicted equilibrium adsorption capacities.

\section{Results and Discussion}

\subsection{Characterization of Egusi Seed Shell}

\subsubsection{Proximate and Elemental Analyses of ESS}

The data collected for the proximate and elemental analyses of Egusi seed shell (ESS) are given in Table 2. For comparative purposes, data from other precursors are also provided. The ESS contains $6.32 \%$ moisture, $69.53 \%$ volatile matter, $4.13 \%$ ash content and $20.02 \%$ fixed carbon. The elemental analysis shows that ESS is 
mainly composed of carbon (47.02\%), hydrogen (5.46\%), nitrogen $(3.16 \%)$ and oxygen $(44.36 \%)$. The amount of nitrogen in ESS is comparatively higher than previously used precursors, while other compositions are nearly same. Being studied for the first time, the ESS precursor has a low ash and high carbon content and is therefore an appropriate raw material for ACs production.

\subsubsection{TGA Analysis of ESS}

The carbonization temperature of ACs production depends on the thermal behavior of precursor (ESS), therefore, ESS was subjected to thermogravimetric analysis (TGA), TGA profile is given in Figure 1. TGA suggests three stages of weight loss during pyrolysis. The first stage shows $9.98 \%$ weight loss in the temperature range of $27^{\circ} \mathrm{C}-160^{\circ} \mathrm{C}$, quite possibly due to removal of surface bound water and moisture. The second stage, characterized by a weight loss of $52.34 \%$, from $160^{\circ} \mathrm{C}$ to $400^{\circ} \mathrm{C}$, could be due to the decomposition of cellulose, hemicellulose

Table 2. Proximate and ultimate analyses of Egusi seed shells.

\begin{tabular}{|c|c|c|c|c|c|}
\hline \multirow[b]{2}{*}{ Property } & \multicolumn{4}{|c|}{ Percentage (wt $\%$ ) } & \multirow{2}{*}{$\begin{array}{c}\text { ASTM test } \\
\text { Standard }\end{array}$} \\
\hline & $\begin{array}{l}\text { Egusi seed shells } \\
\text { (Present study) }\end{array}$ & $\begin{array}{c}\text { Sherry stones } \\
\text { shells [17] }\end{array}$ & $\begin{array}{c}\text { Fox nuts } \\
\text { shells [15] }\end{array}$ & $\begin{array}{c}\text { Coconut } \\
\text { shells [21] }\end{array}$ & \\
\hline \multicolumn{6}{|c|}{ Proximate analysis } \\
\hline Moisture & 6.32 & 2.67 & 4.0 & 5.62 & D $1762-84$ \\
\hline Volatiles & 69.53 & 78.5 & 70.1 & 71.4 & D 5832-98 \\
\hline Ash & 4.13 & 0.17 & 5 & 1.11 & D $2866-11$ \\
\hline $\begin{array}{c}\text { Fixed } \\
\text { carbon }^{\mathrm{a}}\end{array}$ & 20.02 & 21.33 & 20.9 & 23.3 & \\
\hline \multicolumn{6}{|c|}{ Elemental analysis } \\
\hline Carbon & 47.02 & 48.72 & 42.3 & 48.7 & \\
\hline Hydrogen & 5.46 & 6.41 & 4.3 & 6.34 & \\
\hline Nitrogen & 3.16 & 1.85 & 0.82 & 1.52 & \\
\hline Sulphur & n.d $d^{b}$ & $\mathrm{n} . \mathrm{d}^{\mathrm{a}}$ & 0.07 & 0.038 & \\
\hline Oxygen $^{a}$ & 44.36 & 43.02 & 52.51 & 43.4 & \\
\hline
\end{tabular}

${ }^{b}$ no detection; ${ }^{a}$ by difference.

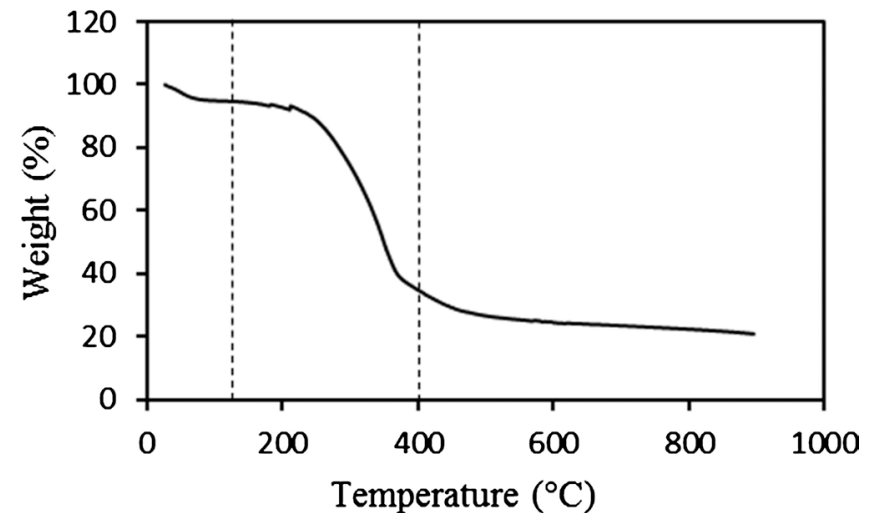

Figure 1. TGA of ESS. 
and few lignin [20] [39]. In final stage of pyrolysis, $400^{\circ} \mathrm{C}$ and above (gradually and continuously up to $900^{\circ} \mathrm{C}$ ), the weight loss $(16.80 \%)$ corresponds to the decomposition of lignin and formation of carbon material. The residue was about $22.38 \%$. Hence, the temperature range of $400^{\circ} \mathrm{C}$ to $700^{\circ} \mathrm{C}$ was considered as the carbonization temperature in this study.

\subsubsection{FTIR Analysis of ESS}

The FTIR spectrum of ESS is presented in Figure 2. The broad peak appearing at $3389.6 \mathrm{~cm}^{-1}$ is attributed to the $\mathrm{O}-\mathrm{H}$ bond stretching vibration of water, cellulose, hemicellulose and lignin (main constituent of ESS) [18]. The two peaks at 2928.3 and $2862.7 \mathrm{~cm}^{-1}$ are due to symmetric and asymmetric stretching vibration of methyl group, and the peak at $1737.6 \mathrm{~cm}^{-1}$ indicates the stretching vibration of carbonyl group $(\mathrm{C}=\mathrm{O})$ of hemicellulose and lignin [18]. The bands found in the $1653.4-1515.6 \mathrm{~cm}^{-1}$ range are responsible for N-H bond stretching. More vibrations were observed between 1459 and $1377.3 \mathrm{~cm}^{-1}$ can be ascribed to aliphatic and aromatic $\mathrm{C}-\mathrm{H}$ groups in the plane deformation vibration. The bands between of $1261.0-1041.7 \mathrm{~cm}^{-1}$ could be assigned to the $\mathrm{C}-\mathrm{O}$ stretching vibration of carboxylic acid and alcohols [18].

\subsection{Design of Experiments Using Box-Behnken Design}

The Iodine Number (IN), Methylene Blue Number (MBN) and ACs yield were chosen as responses for the Box-Behnken design. The experimental matrix, together with the experimental and predicted values of the responses are given in Table 3. Experiments 13 to 15 were performed when all the studied parameters were at the center of the studied domain in order to determine the experimental error and the reproducibility of data.

\subsubsection{Iodine Absorption}

The results obtained from Iodine adsorption are given in Table 3. The IN values of ACP and ACZ are in range $342.27-479.49 \mathrm{mg} \cdot \mathrm{g}^{-1}$ and $350.44-539.98 \mathrm{mg} \cdot \mathrm{g}^{-1}$

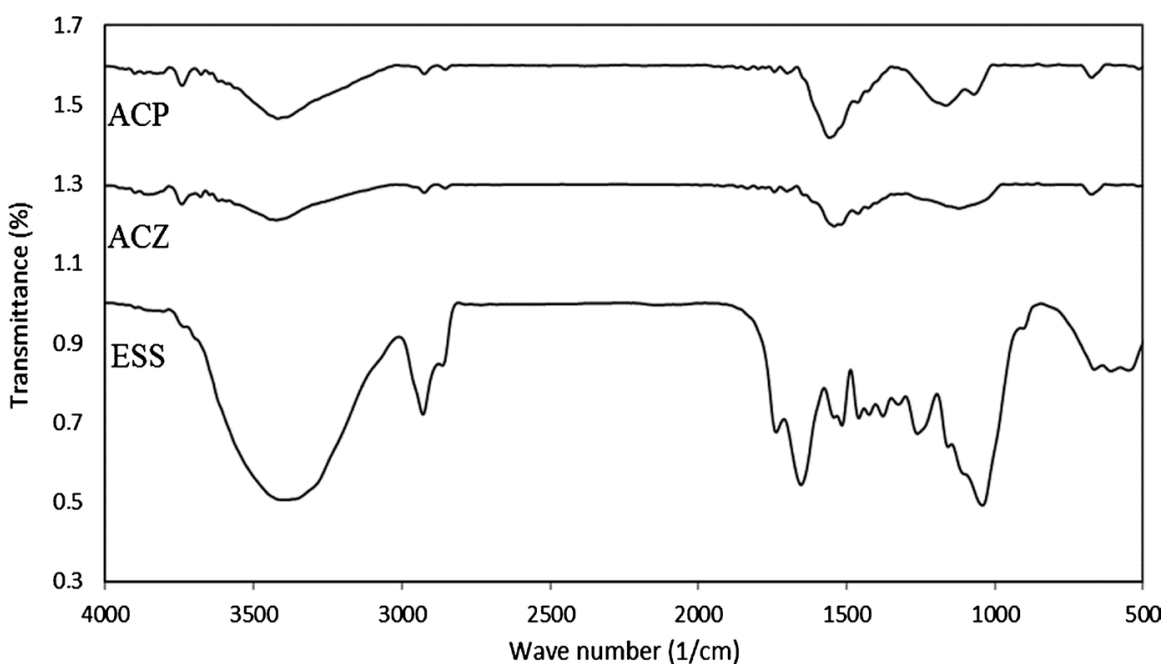

Figure 2. FTIR spectra of ESS, ACP and ACZ. 
Table 3. Experimental design matrix for optimization using BBD.

\begin{tabular}{|c|c|c|c|c|c|c|c|c|c|}
\hline \multirow{2}{*}{$\begin{array}{c}\begin{array}{c}\mathrm{H}_{3} \mathrm{PO}_{4} \text { activation } \\
\text { (Model 1) }\end{array} \\
\text { Run order }\end{array}$} & \multicolumn{3}{|c|}{ ACP preparation parameters } & \multicolumn{2}{|c|}{$\mathrm{IN}(\mathrm{mg} / \mathrm{g})-Y_{1}$} & \multicolumn{2}{|c|}{$\operatorname{MBN}(\mathrm{mg} / \mathrm{g})-Y_{2}$} & \multicolumn{2}{|c|}{ Yield (\%) - $Y_{3}$} \\
\hline & $\begin{array}{c}\mathrm{H}_{3} \mathrm{PO}_{4} \\
\text { Concentration }\left(x_{1}\right)\end{array}$ & $\begin{array}{l}\text { Carbonization } \\
\text { temperature }\left(x_{2}\right)\end{array}$ & $\begin{array}{l}\text { Carbonization } \\
\text { time }\left(x_{3}\right)\end{array}$ & Exp. value & Pre. value & Exp. value & $\begin{array}{l}\text { Pre. } \\
\text { value }\end{array}$ & $\begin{array}{l}\text { Exp. } \\
\text { value }\end{array}$ & $\begin{array}{l}\text { Pre. } \\
\text { value }\end{array}$ \\
\hline 1 & $2(-1)$ & $400(-1)$ & $75(0)$ & 342.27 & 341.43 & 107.05 & 128.68 & 52.53 & 51.84 \\
\hline 2 & $10(1)$ & $400(-1)$ & $75(0)$ & 347.67 & 369.88 & 249.79 & 278.67 & 46.36 & 45.53 \\
\hline 3 & $2(-1)$ & $700(1)$ & $75(0)$ & 455.01 & 432.10 & 195.76 & 166.89 & 33.98 & 34.81 \\
\hline 4 & $10(1)$ & $700(1)$ & $75(0)$ & 451.31 & 452.15 & 369.82 & 348.19 & 38.31 & 38.99 \\
\hline 5 & $2(-1)$ & $550(0)$ & $30(-1)$ & 373.32 & 389.30 & 166.19 & 175.17 & 48.26 & 49.58 \\
\hline 6 & $10(1)$ & $550(0)$ & $30(-1)$ & 441.57 & 434.50 & 364.68 & 366.42 & 40.97 & 42.41 \\
\hline 7 & $2(-1)$ & $550(0)$ & $120(1)$ & 392.92 & 399.99 & 191.68 & 189.94 & 38.68 & 37.23 \\
\hline 8 & $10(1)$ & $550(0)$ & $120(1)$ & 418.58 & 402.60 & 338.95 & 329.97 & 43.58 & 42.27 \\
\hline 9 & $6(0)$ & $400(-1)$ & $30(-1)$ & 446.84 & 431.71 & 346.00 & 315.39 & 46.57 & 45.95 \\
\hline 10 & $6(0)$ & $700(1)$ & $30(-1)$ & 497.49 & 503.73 & 374.14 & 394.03 & 39.91 & 37.78 \\
\hline 11 & $6(0)$ & $400(-1)$ & $120(1)$ & 412.53 & 406.30 & 349.23 & 329.33 & 41.19 & 43.32 \\
\hline 12 & $6(0)$ & $700(1)$ & $120(1)$ & 492.79 & 507.93 & 327.81 & 358.42 & 27.31 & 27.93 \\
\hline 13 & $6(0)$ & $550(0)$ & $75(0)$ & 464.84 & 466.04 & 265.17 & 265.79 & 44.66 & 43.36 \\
\hline 14 & $6(0)$ & $550(0)$ & $75(0)$ & 465.01 & 466.04 & 266.11 & 265.79 & 43.73 & 43.36 \\
\hline 15 & $6(0)$ & $550(0)$ & $75(0)$ & 468.28 & 466.04 & 266.11 & 265.79 & 41.70 & 43.36 \\
\hline $\begin{array}{l}\mathrm{ZnCl}_{2} \text { activation } \\
\quad(\text { Model } 2)\end{array}$ & \multicolumn{3}{|c|}{ ACZ preparation parameters } & \multicolumn{2}{|c|}{$\mathrm{IN}(\mathrm{mg} / \mathrm{g})-Y_{4}$} & \multicolumn{2}{|c|}{$\mathrm{MBN}(\mathrm{mg} / \mathrm{g})-Y_{5}$} & \multicolumn{2}{|c|}{ Yield (\%) $-Y_{6}$} \\
\hline Run order & $\begin{array}{c}\mathrm{ZnCl}_{2} \\
\text { Concentration }\left(x_{1}\right)\end{array}$ & $\begin{array}{l}\text { Carbonization } \\
\text { temperature }\left(x_{2}\right)\end{array}$ & $\begin{array}{l}\text { Carbonization } \\
\text { time }\left(x_{3}\right)\end{array}$ & Exp. value & Pre. value & Exp. value & $\begin{array}{l}\text { Pre. } \\
\text { value }\end{array}$ & $\begin{array}{l}\text { Exp. } \\
\text { value }\end{array}$ & $\begin{array}{l}\text { Pre. } \\
\text { value }\end{array}$ \\
\hline 1 & $2(-1)$ & $400(-1)$ & $75(0)$ & 350.44 & 359.12 & 149.88 & 137.30 & 49.93 & 51.62 \\
\hline 2 & $10(1)$ & $400(-1)$ & $75(0)$ & 431.83 & 456.77 & 203.91 & 225.85 & 45.36 & 43.38 \\
\hline 3 & $2(-1)$ & $700(1)$ & $75(0)$ & 452.79 & 427.85 & 158.03 & 136.10 & 31.65 & 33.63 \\
\hline 4 & $10(1)$ & $700(1)$ & $75(0)$ & 516.25 & 507.57 & 374.25 & 386.83 & 38.71 & 37.03 \\
\hline 5 & $2(-1)$ & $550(0)$ & $30(-1)$ & 357.96 & 378.21 & 148.86 & 182.28 & 48.26 & 46.74 \\
\hline 6 & $10(1)$ & $550(0)$ & $30(-1)$ & 503.27 & 507.27 & 351.14 & 350.05 & 39.23 & 41.38 \\
\hline 7 & $2(-1)$ & $550(0)$ & $120(1)$ & 441.94 & 437.94 & 150.90 & 151.99 & 40.71 & 38.56 \\
\hline 8 & $10(1)$ & $550(0)$ & $120(1)$ & 506.51 & 486.25 & 356.93 & 323.51 & 37.56 & 39.08 \\
\hline 9 & $6(0)$ & $400(-1)$ & $30(-1)$ & 492.60 & 463.66 & 336.17 & 315.33 & 44.34 & 44.17 \\
\hline 10 & $6(0)$ & $700(1)$ & $30(-1)$ & 539.98 & 544.66 & 359.67 & 348.18 & 36.78 & 36.32 \\
\hline 11 & $6(0)$ & $400(-1)$ & $120(1)$ & 508.93 & 504.25 & 228.38 & 239.87 & 42.78 & 43.24 \\
\hline 12 & $6(0)$ & $700(1)$ & $120(1)$ & 513.84 & 542.78 & 345.96 & 366.81 & 26.60 & 26.77 \\
\hline 13 & $6(0)$ & $550(0)$ & $75(0)$ & 507.30 & 502.39 & 235.52 & 272.23 & 41.91 & 40.71 \\
\hline 14 & $6(0)$ & $550(0)$ & $75(0)$ & 499.12 & 502.39 & 281.40 & 272.23 & 39.20 & 40.71 \\
\hline 15 & $6(0)$ & $550(0)$ & $75(0)$ & 500.76 & 502.39 & 299.76 & 272.23 & 41.01 & 40.71 \\
\hline
\end{tabular}


respectively. Statistical analysis was carried out to determine the significant variables in IN values (Table 4). Two quadratic regression models were used to predict the optimal IN value of ACP $\left(Y_{1}\right)$ and ACZ $\left(Y_{4}\right)$ (Equations (9) and (12)) respectively).

$$
\begin{aligned}
Y_{1}= & 466.044+11.951 x_{1}+43.412 x_{2}-5.301 x_{3}-61.397 x_{1}^{2}-5.581 x_{2}^{2} \\
& +1.953 x_{3}^{2}-2.274 x_{1} x_{2}-10.648 x_{1} x_{3}+7.402 x_{2} x_{3} \\
Y_{4}= & 502.395+44.342 x_{1}+29.882 x_{2}+9.678 x_{3}-62.992 x_{1}^{2}-1.575 x_{2}^{2} \\
& +13.016 x_{3}^{2}-4.481 x_{1} x_{2}-20.184 x_{1} x_{3}-10.62 x_{2} x_{3}
\end{aligned}
$$

\begin{tabular}{|c|c|c|c|c|c|c|c|c|c|c|}
\hline \multirow{2}{*}{ Source } & \multirow{2}{*}{ DF } & \multicolumn{3}{|c|}{ IN } & \multicolumn{3}{|c|}{ MBN } & \multicolumn{3}{|c|}{ Yield } \\
\hline & & MS & F-value & $\mathrm{P}$-value & MS & F-value & $\mathrm{P}$-value & MS & F-value & $\mathrm{P}$-value \\
\hline Model 1 & 9 & 3469.8 & 8.10 & $0.017^{* *}$ & $10,313.5$ & 9.49 & $0.012^{* *}$ & 54.306 & 11.15 & $0.008^{\star *}$ \\
\hline$x_{1}$ & 1 & 1142.7 & 2.67 & 0.163 & $54,873.4$ & 50.48 & $0.001^{\star *}$ & 2.237 & 0.46 & 0.528 \\
\hline$x_{2}$ & 1 & $15,076.7$ & 35.18 & $0.002^{* *}$ & 5802.5 & 5.34 & $0.069^{*}$ & 277.772 & 57.01 & $0.001^{* *}$ \\
\hline$x_{3}$ & 1 & 224.8 & 0.52 & 0.501 & 234.9 & 0.22 & 0.662 & 77.813 & 15.97 & $0.010^{* *}$ \\
\hline$x_{1}^{2}$ & 1 & $13,918.6$ & 32.48 & $0.002^{* *}$ & $13,095.7$ & 12.05 & $0.018^{* *}$ & 11.693 & 2.40 & 0.182 \\
\hline$x_{2}^{2}$ & 1 & 115.0 & 0.27 & 0.627 & 2192.1 & 2.02 & 0.215 & 20.355 & 4.18 & $0.096^{*}$ \\
\hline$x_{2}^{2}$ & 1 & 14.1 & 0.03 & 0.863 & $12,911.1$ & 11.88 & $0.018^{* *}$ & 19.033 & 3.91 & 0.105 \\
\hline$x_{1} x_{2}$ & 1 & 20.7 & 0.05 & 0.835 & 245.3 & 0.23 & 0.655 & 27.563 & 5.66 & $0.063^{*}$ \\
\hline$x_{1} x_{3}$ & 1 & 453.5 & 1.06 & 0.351 & 656.0 & 0.60 & 0.472 & 37.149 & 7.62 & $0.040^{* *}$ \\
\hline$x_{2} x_{3}$ & 1 & 219.1 & 0.51 & 0.507 & 613.8 & 0.56 & 0.486 & 13.032 & 2.67 & 0.163 \\
\hline Residual Error & 5 & 428.5 & & & 1087.1 & & & 4.873 & & \\
\hline \multirow[t]{2}{*}{ Lack-of-Fit } & 3 & 711.7 & 189.05 & $0.005^{* *}$ & 1811.7 & 6177.11 & $0.000^{* *}$ & 6.594 & 2.88 & 0.268 \\
\hline & & $\mathrm{R}^{2} 93.58 \%$ & Adj R ${ }^{2} 82.02 \%$ & & $\mathrm{R}^{2} 94.47 \%$ & Adj R ${ }^{2} 84.51 \%$ & & $\mathrm{R}^{2} 95.25 \%$ & Adj R ${ }^{2} 86.71 \%$ & \\
\hline Source & DF & Adj MS & F-value & $\mathrm{P}$-value & Adj MS & F-value & P-value & Adj MS & F-value & $\mathrm{P}$-value \\
\hline Model 2 & 9 & 4626.0 & 5.78 & $0.034^{* *}$ & $11,130.2$ & 8.14 & $0.016^{* *}$ & 51.448 & 8.12 & $0.016^{* *}$ \\
\hline$x_{1}$ & 1 & $15,729.6$ & 19.64 & $0.007^{* *}$ & $57,557.9$ & 42.09 & $0.001^{* *}$ & 11.737 & 1.85 & 0.232 \\
\hline$x_{2}$ & 1 & 7143.6 & 8.92 & $0.031^{* *}$ & $12,764.9$ & 9.33 & $0.028^{* *}$ & 296.096 & 46.73 & $0.001^{* *}$ \\
\hline$x_{3}$ & 1 & 749.3 & 0.94 & 0.378 & 1614.9 & 1.18 & 0.327 & 54.915 & 8.67 & $0.032^{\star *}$ \\
\hline$x_{1}^{2}$ & 1 & $14,650.9$ & 18.30 & $0.008^{* *}$ & $12,484.5$ & 9.13 & $0.029^{* *}$ & 18.866 & 2.98 & 0.145 \\
\hline$x_{2}^{2}$ & 1 & 9.2 & 0.01 & 0.919 & 204.4 & 0.15 & 0.715 & 8.923 & 1.41 & 0.289 \\
\hline$x_{2}^{2}$ & 1 & 625.5 & 0.78 & 0.417 & 5297.8 & 3.87 & 0.106 & 8.610 & 1.36 & 0.296 \\
\hline$x_{1} x_{2}$ & 1 & 80.3 & 0.10 & 0.764 & 6576.4 & 4.81 & $0.080^{*}$ & 33.814 & 5.34 & $0.069^{*}$ \\
\hline$x_{1} x_{3}$ & 1 & 1629.7 & 2.04 & 0.213 & 3.5 & 0.00 & 0.962 & 8.644 & 1.36 & 0.295 \\
\hline$x_{2} x_{3}$ & 1 & 451.1 & 0.56 & 0.487 & 2213.1 & 1.62 & 0.259 & 18.576 & 2.93 & 0.148 \\
\hline Residual Error & 5 & 800.8 & & & 1549.5 & & & 6.336 & & \\
\hline \multirow[t]{2}{*}{ Lack-of-Fit } & 3 & 1322.1 & 70.67 & $0.014^{* *}$ & 1549.5 & 1.42 & 0.439 & 9.291 & 4.88 & 0.175 \\
\hline & & $\mathrm{R}^{2} 91.23 \%$ & Adj $R^{2} 75.44 \%$ & & $\mathrm{R}^{2} 93.61 \%$ & Adj $\mathrm{R}^{2} 82.11 \%$ & & $\mathrm{R}^{2} 93.60 \%$ & Adj R ${ }^{2} 82.07 \%$ & \\
\hline
\end{tabular}

Table 4. Analysis of variance (ANOVA) for the regression model for IN, MBN and ACs Yield.

${ }^{*}$ most significant, ${ }^{*}$ less significant. 
By applying the statistical model ANOVA, (see Table 4), it is clearly seen that the experimental and predicted values are in good agreement, since the correlation coefficient of the model is close to unity for both ACs $\left(R^{2}=0.93\right.$ and 0.91 for ACP and ACZ respectively). The significant terms are $x_{2}$ and $x_{1}^{2}$ for ACP, and $x_{1}, x_{2}$ and $x_{1}^{2}$ for ACZ, given that the $p$-value of these terms are less than 0.05 . It is also noted that IN values are significantly affected by the concentration of activating agent $\left(x_{1}\right)$ and carbonization temperature $\left(x_{2}\right)$, while the effect of residence time $\left(x_{3}\right)$ is insignificant. Figure 3 illustrates the response surface plots, obtained by plotting temperature and concentration against IN values, with the residence time kept constant at the center point (75 min). A consistent trend was observed in ACP and ACZ; the IN value increases as the temperature increases. This may be explained by considering that at higher temperatures, there is a greater chance of volatile matter to vaporize from the precursor, causing an increase in pore development and/or formation of new micropores (or active sites) [12] [40], hence an increase in the IN value. Tounsadi et al. (2016) [10] reported similar results. Furthermore, an increase in concentration of activating agent leads to an increase up to a maximum of $6 \mathrm{M}$ for ACP (Figure 3(a)) and $8 \mathrm{M}$ for ACZ (Figure 3(b)) of the IN value. Any further increase in the concentration of activating agents, causes a decrease in the IN value. As the concentration of activating agent increase, the interaction between activating agents and raw material increases and generating porosity [31]. When the concentration of activating agent is too high, two possibilities occur: 1) new micropores do not form, while existing ones are continuously enlarged [31] and 2), the excess and/or unreacted activating agent blocks the pores [41] resulting to a decrease in microporosity, which is directly link to the Iodine absorption capacity. Lower concentration of activating agent resulted to lower IN values, probably due to incomplete reaction between activating agent and the raw material.
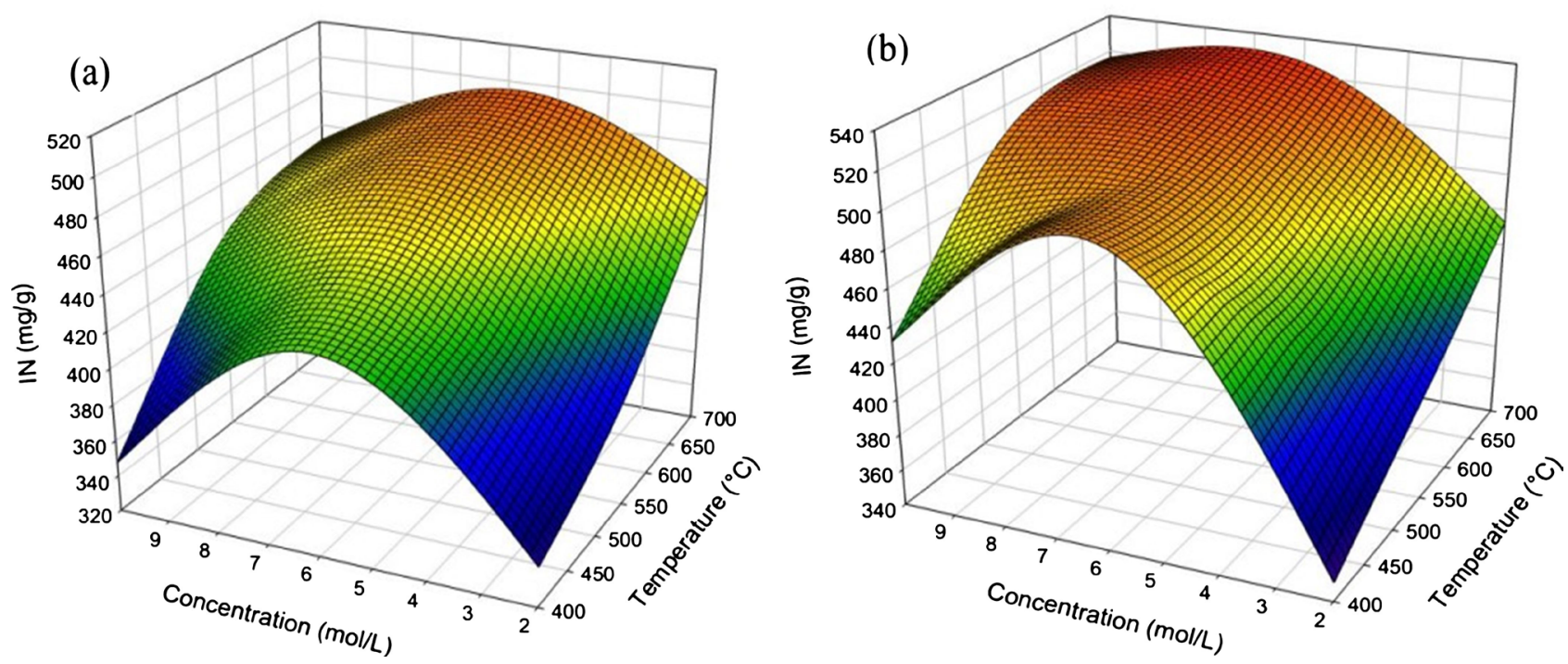

Figure 3. Response surface plot for the effect of temperature and concentration on IN value of (a) ACP, (b) ACZ. 


\subsubsection{Methylene Blue Absorption}

For the methylene blue adsorption, the values of MBN varied from 107.05 to $374.14 \mathrm{mg} \cdot \mathrm{g}^{-1}$ for ACP and 149.88 to $374.25 \mathrm{mg} \cdot \mathrm{g}^{-1}$ for ACZ (see Table 3). In both ACs, the MBN was significantly influenced by the concentration of activating agent $\left(x_{1}\right)$ and activation temperature $\left(x_{2}\right)$, see Table 4 . For the prediction of MB adsorption capacity, quadratic regression model Equations ((11) and (12)) were used for ACP $\left(Y_{2}\right)$ and $\mathrm{ACZ}\left(Y_{5}\right)$, respectively.

$$
\begin{aligned}
Y_{2}= & 265.797+82.82 x_{1}+26.932 x_{2}-5.419 x_{3}-59.555 x_{1}^{2}+24.366 x_{2}^{2} \\
& +59.133 x_{3}^{2}+7.83 x_{1} x_{2}-12.806 x_{1} x_{3}-12.387 x_{2} x_{3} \\
Y_{5}= & 272.227+84.822 x_{1}+39.945 x_{2}-14.208 x_{3}-58.148 x_{1}^{2}+7.441 x_{2}^{2} \\
& +37.879 x_{3}^{2}+40.545 x_{1} x_{2}+0.938 x_{1} x_{3}+23.522 x_{2} x_{3}
\end{aligned}
$$

The correlation coefficients $\left(R^{2}\right)$ were found to be 0.94 and 0.93 respectively (see Table 4), which indicate good fitting of the described models. The significant terms of the selected models given in Table 4 are $x_{1}, x_{2}, x_{1}^{2}$ and $x_{3}^{2}$ ( $p$-values are less than 0.05). Figure 4 depicts the response surface plots based on the interactions and effect of concentration $\left(x_{1}\right)$ and temperature $\left(x_{2}\right)$ on methylene blue adsorption value. The residence time was kept fixed at the center point for all plots. The value of $\mathrm{MBN}$ increases as a function of two significant variables (concentration and temperature) for both ACP and ACZ. The observed results are in agreement with that reported by Tan et al. [9], who indicated that the impregnation ratio and temperature have significant effect on the pore size and structure of $\mathrm{AC}$ from mango stem peel using $\mathrm{KOH}$ as activating agent. Similarly, Kouotou et al. [13] using $\mathrm{H}_{3} \mathrm{PO}_{4}$ and Sayğili and Güzel [18] using $\mathrm{ZnCl}_{2}$, found well-developed mesopores of ACs with increasing value of studied factors (i.e. concentration and temperature). The increase in $\mathrm{MBN}$ value with the concentration and temperature, was also considered to be due to the depolymerization of cellulose and distillation of tar from the carbon at high temperatures
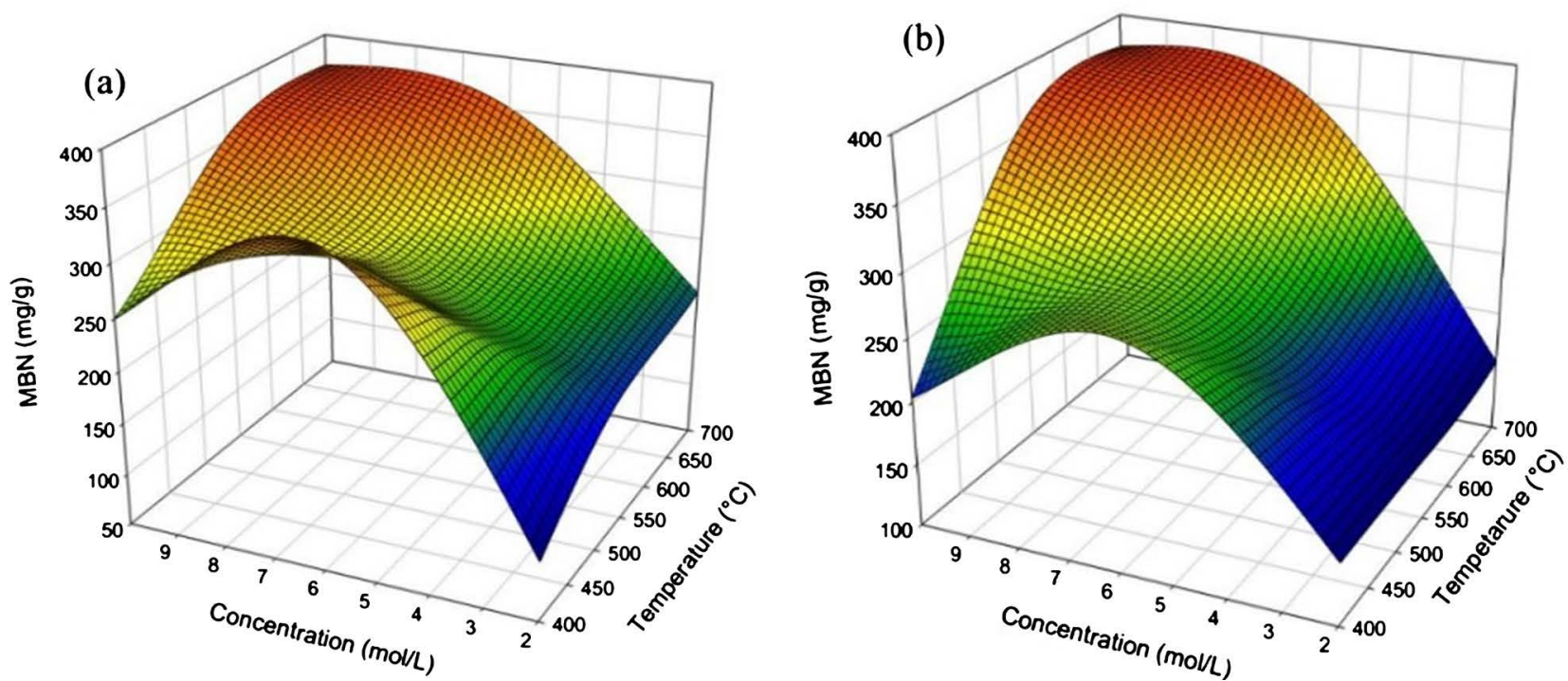

Figure 4. Response surface plot for the effect of temperature and concentration on MBN value of (a) ACP, (b) ACZ. 
(above $500^{\circ} \mathrm{C}$ ), which generate more mesopores in the resultant ACs [40].

\subsubsection{Activated Carbon Yield}

The resultant yield of ACs is a key response factor directed to production. A set of experiment were performed with variable experimental conditions, in order to determine the optimal conditions for obtaining maximum yield of product (i.e. ACP and ACZ). According to the results (Table 3), the maximum yield of ACP and $\mathrm{ACZ}$ was achieved at low concentration of activating agent with least carbonization time, (experiment 1), whereas, minimum yield was obtained at high temperature and longer residence time (experiment 12). The ACP yield was in the range $27.31 \%-52.25 \%$ and similar to the ACZ yield (26.60\% - 49.93\%). The results of ANOVA for the response of ACP yield $\left(Y_{3}\right)$ and ACZ yield $\left(Y_{6}\right)$ (Equations (13) and (14)) and their correlation coefficients are given in Table 4.

$$
\begin{aligned}
Y_{3}= & 43.363-0.529 x_{1}-5.893 x_{2}-3.119 x_{3}+1.78 x_{1}^{2}-2.348 x_{2}^{2} \\
& -2.27 x_{3}^{2}+2.625 x_{1} x_{2}+3.048 x_{1} x_{3}-1.805 x_{2} x_{3} \\
Y_{6}= & 40.707-1.211 x_{1}-6.084 x_{2}-2.62 x_{3}+2.26 x_{1}^{2}-1.555 x_{2}^{2} \\
& -1.527 x_{3}^{2}+2.907 x_{1} x_{2}+1.47 x_{1} x_{3}-2.155 x_{2} x_{3}
\end{aligned}
$$

All the terms, $X_{2}, x_{3}, X_{1} x_{2}$ and $x_{1} x_{3}$ and $x_{1}, x_{3}, x_{1} x_{2}$ for ACP and ACZ respectively (see Table 4) are significant. Figure 5 illustrates the response surface graph of carbonization temperature $\left(x_{2}\right)$ and residential time $\left(x_{3}\right)$ against the obtained yield. The concentration was maintained at the center point $(6 \mathrm{M})$. It is observed from the graph that an increase in activation temperature leads to a decrease in the obtainable yield, whereas, residence time does not significantly affect the response. This decrease in yield may be attributed to the fact that an increase in activation temperature increases the quantity of carbon burn-off and the continuous liberation of the volatile matter which is reflected as a loss of adsorbent
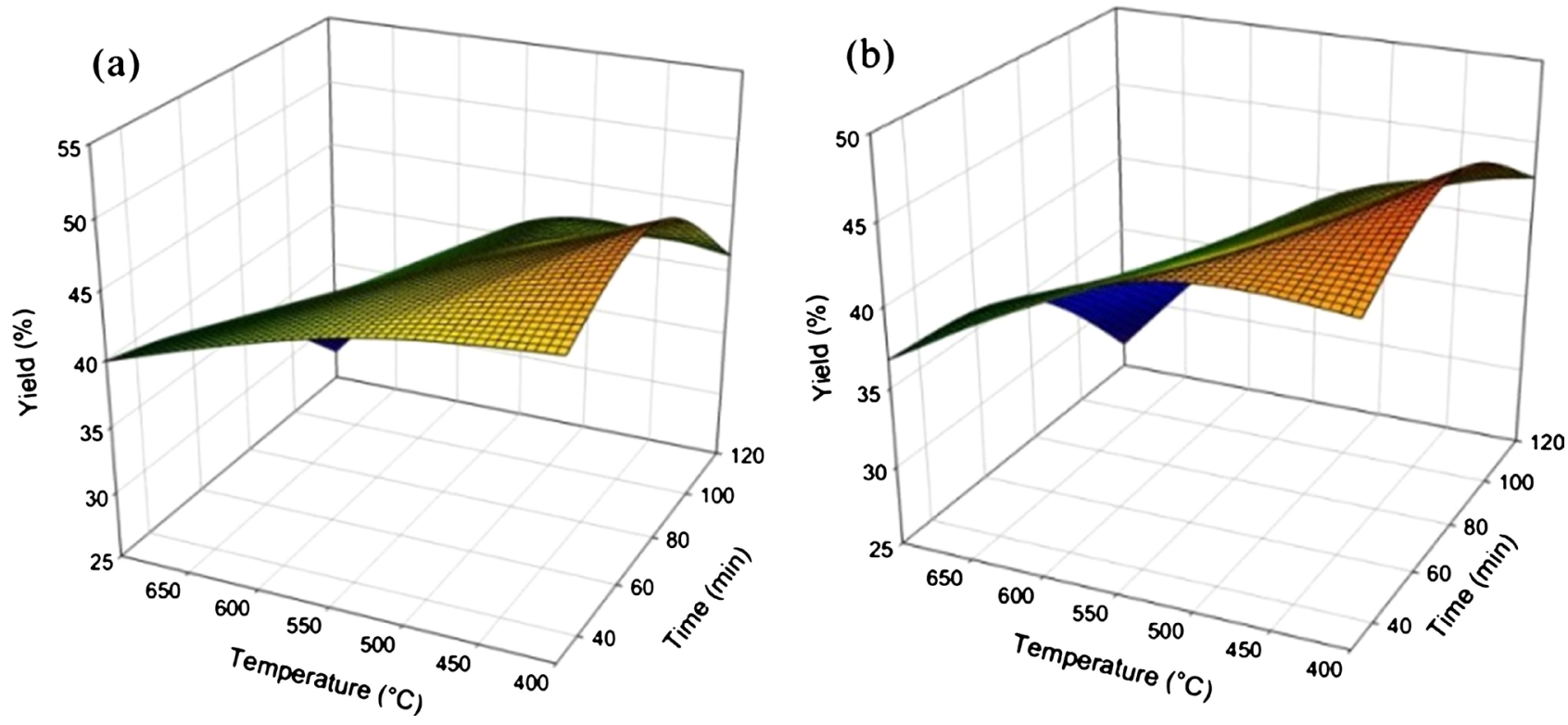

Figure 5. Response surface plot for the effect of temperature and time on yield of (a) ACP, (b) ACZ. 
material. The maximum yield was achieved when the temperature and residence time were maintained at their lowest value and the concentration was kept constant at the central point. The obtained results are in accordance with those from the literature [9] [20] [23] and it can therefore be concluded that, the activation temperature has a greater impact compared to the residence time on the AC yield.

\subsubsection{Optimization Process and Validation Test}

The optimization process and method validation are quite essential in setting up the optimum conditions for maximum AC yield, high iodine and methylene blue adsorption capacity from the precursor. However, it is difficult to optimize these three responses under the same conditions because the zone of interest of the factors is different. The desirability function was then applied using Minitab 16 software in order to consolidate the three factors by considering the same weight for all the factors on the three responses [13] [29]. The results of this optimization are presented in Table 5. The experimental responses are close to the predicted value, there was no significant difference between predicted and experimental data. A residence time of $30 \mathrm{~min}$ led to maximum yield irrespective of the activating agent. The optimum conditions for $\mathrm{ACP}$ are $\mathrm{H}_{3} \mathrm{PO}_{4}$ concentration of $7 \mathrm{M}$ at a carbonization temperature of $633^{\circ} \mathrm{C}$, and $\mathrm{ZnCl}_{2}$ concentration of 10 $\mathrm{M}$ and carbonization temperature of $698^{\circ} \mathrm{C}$ for ACZ. These results show that, the $\mathrm{AC}$ obtained through $\mathrm{H}_{3} \mathrm{PO}_{4}$ activation require less concentration at comparative low temperature compared to that obtained from $\mathrm{ZnCl}_{2}$.

\subsection{Physicochemical Characteristics}

\subsubsection{Specific Surface Area}

The surface area of ACs was determinate through multipoint BET method by keeping the relative pressure $\left(P / P_{0}\right)$ in the range of 0.02 to 0.3 . The pore size parameters were calculated using Dubinin-Astakhov method. The results are summarized in Table 6. The linear plot of the multipoint BET (Figure 6) gave a surface area $\left(S_{\text {BET }}\right)$ of $1058.91 \mathrm{~m}^{2} \cdot \mathrm{g}^{-1}$ and $1008.99 \mathrm{~m}^{2} \cdot \mathrm{g}^{-1}$ for ACP and ACZ respectively. The total pore volume was found to be 0.663 and $0.594 \mathrm{~cm}^{3} \cdot \mathrm{g}^{-1}$, and the average pore size of ACP and ACZ were obtained as 1.84 and $2.02 \mathrm{~nm}$ respectively. The average pore size indicates that the prepared ACs are microporous according to IUPAC classification [14]. Hence, both ACs show similar characteristic even though prepared at different carbonization temperature and concentration of activating agent.

Table 5. Model validation.

\begin{tabular}{|c|c|c|c|c|c|c|c|c|c|c|c|c|}
\hline & \multirow{2}{*}{$\begin{array}{c}X_{1} \\
(\mathrm{~mol} / \mathrm{L})\end{array}$} & \multirow{2}{*}{$\begin{array}{c}x_{2} \\
\left({ }^{\circ} \mathrm{C}\right)\end{array}$} & \multirow{2}{*}{$\begin{array}{c}x_{3} \\
(\mathrm{~min})\end{array}$} & \multicolumn{3}{|c|}{ IN (mg/g) } & \multicolumn{3}{|c|}{ MBN (mg/g) } & \multicolumn{3}{|c|}{ Yield (\%) } \\
\hline & & & & Pred. & Exp. & Error & Pred. & Exp. & Error & Pred. & Exp. & Error \\
\hline $\mathrm{ACP}$ & 7 & 633 & 30 & 492.83 & 496.24 & 0.69 & 382.55 & 378.47 & 1.07 & 40.77 & 43.64 & 6.58 \\
\hline ACZ & 10 & 698 & 30 & 541.26 & 535.41 & 1.08 & 413.48 & 410.11 & 0.82 & 38.86 & 36.07 & 7.18 \\
\hline
\end{tabular}


Table 6. Chemical, physical and textural characteristics of ACs.

\begin{tabular}{|c|c|c|c|c|c|c|c|c|}
\hline \multicolumn{5}{|c|}{ Textural properties } & \multicolumn{4}{|c|}{ Elemental analysis (\%) } \\
\hline & $\begin{array}{c}\text { BET surface area } \\
\left(\mathrm{m}^{2} / \mathrm{g}\right)\end{array}$ & $\begin{array}{l}\text { Pore volume } \\
\quad(\mathrm{cc} / \mathrm{g})\end{array}$ & $\begin{array}{l}\text { Pore size } \\
\quad(\mathrm{nm})\end{array}$ & & $\mathrm{C}$ & $\mathrm{H}$ & $\mathrm{N}$ & $\mathrm{O}^{\mathrm{a}}$ \\
\hline $\mathrm{ACP}$ & 1058.91 & 0.66 & 1.84 & & 57.50 & 0.18 & n. $\mathrm{d}^{\mathrm{b}}$ & 42.35 \\
\hline \multirow[t]{3}{*}{$\mathrm{ACZ}$} & 1008.99 & 0.59 & 2.02 & & 71.55 & 0.39 & 0.99 & 27.07 \\
\hline & & Boehm titratio & (mmol.g & & & & & \\
\hline & Carboxylic & Lactonic & Phenolic & Acidic & Basic & & & $\mathrm{pH}_{\mathrm{PZC}}^{\mathrm{c}}$ \\
\hline $\mathrm{ACP}$ & 0.71 & 0.47 & 0.39 & 1.57 & 0.43 & & & 4.00 \\
\hline $\mathrm{ACZ}$ & 0.35 & 0.56 & 0.31 & 1.22 & 0.93 & & & 7.00 \\
\hline
\end{tabular}

${ }^{\mathrm{a}}$ calculated by difference; ${ }^{\mathrm{b}}$ no detection; ${ }^{\mathrm{c}} \mathrm{pH}$ of point of zero charge.

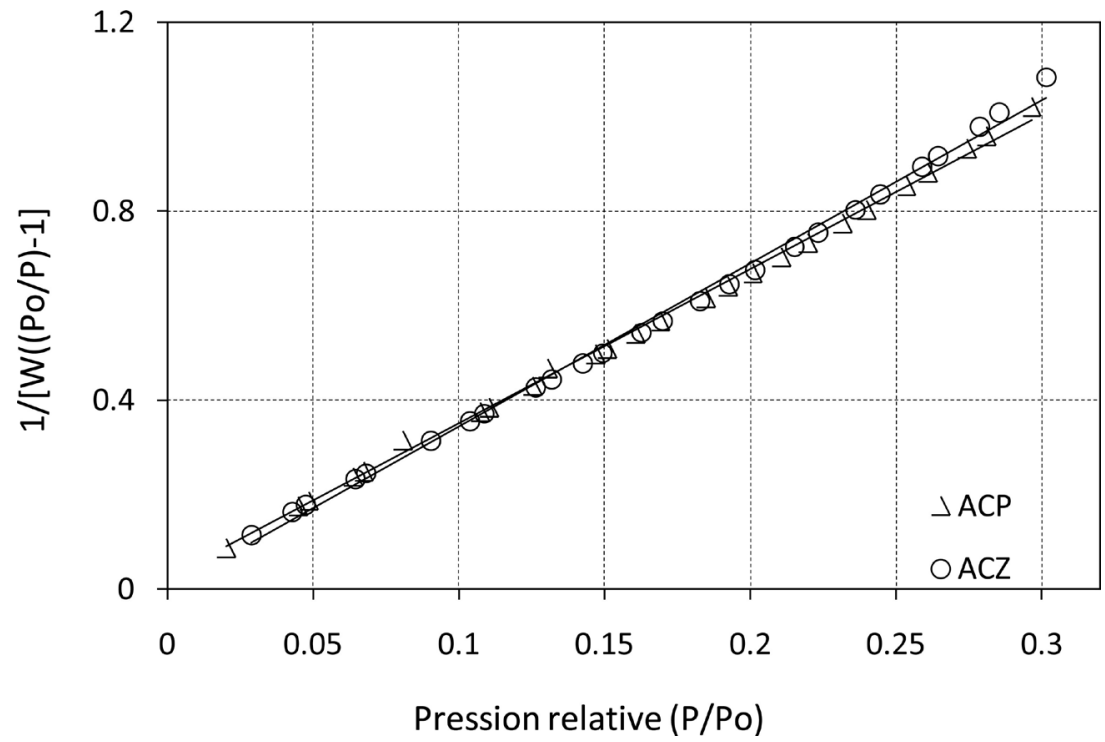

Figure 6. BET specific surface area plots of ACP and ACZ.

\subsubsection{Surface Morphology}

The surface morphology of the precursor (Figure 7(a)), ACP (Figure 7(b)) and ACZ (Figure 7(c)) was assessed by AFM. The images show the presence of well-developed pores and cavities on the surface of ACP and ACZ, and no or undeveloped pores on the precursor's surface. Therefore, surface modification and pore development occurs during activation and carbonization process [42].

\subsubsection{Determination of Surface Functional Groups}

The optimized ACs were subjected to Boehm's titration and FTIR spectroscopy in order to determine the surface functional groups. The results from Boehm's titration show that ACP and ACZ contain higher number of acidic groups (Table 6). The basicity character in ACP is comparatively weaker $\left(0.43 \mathrm{mmol} . \mathrm{g}^{-1}\right)$ than that for ACZ $\left(0.93 \mathrm{mmol} . \mathrm{g}^{-1}\right)$. The $\mathrm{pH}$ of point of zero charge, $\mathrm{pH}_{\mathrm{PZC}}$ was found to be 4.00 and 7.02 for ACP and ACZ respectively.

The FTIR spectra of the ACs are noticeably different from that of the precursor 

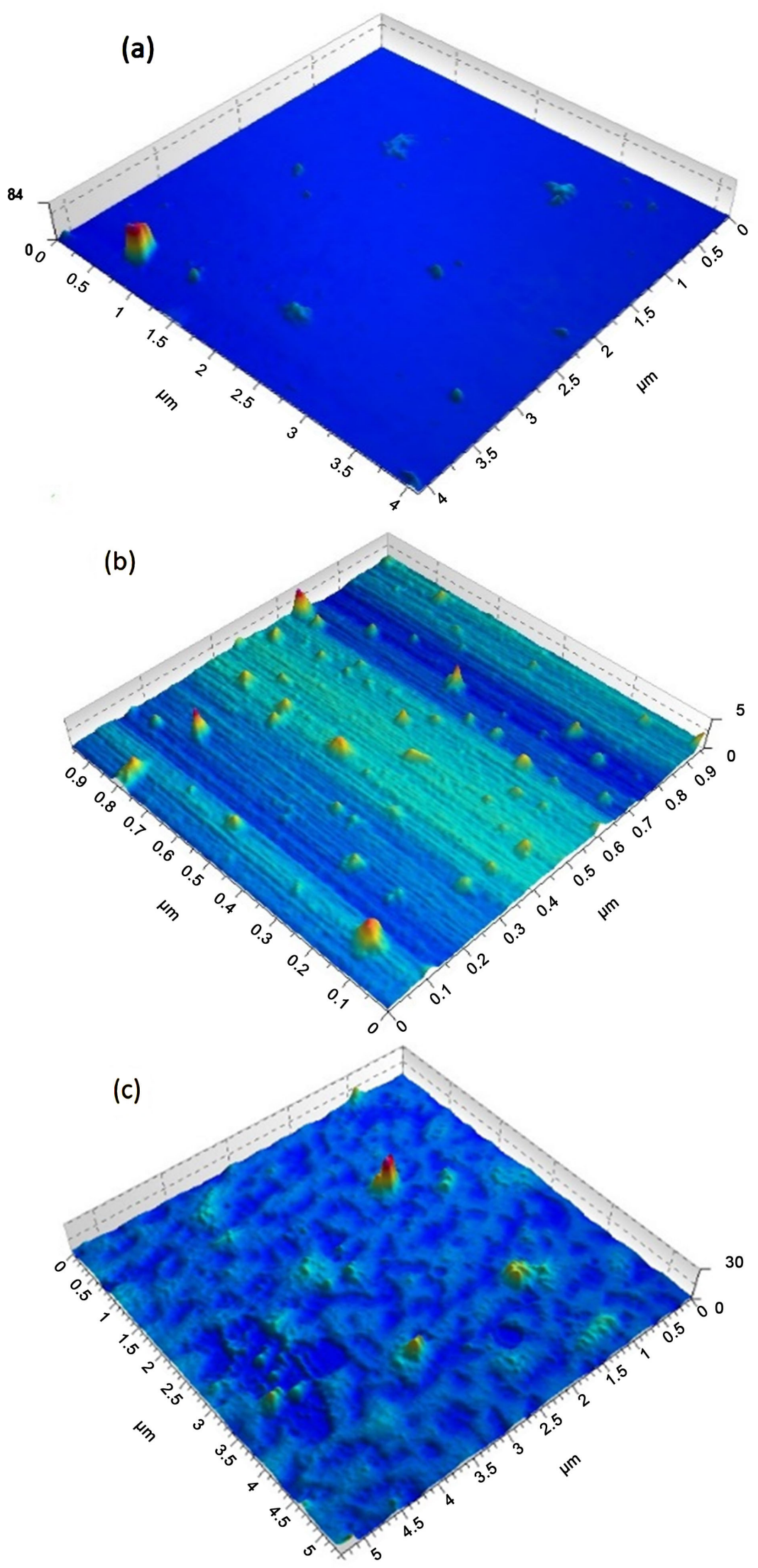

Figure 7. AFM images of (a) precursor, (b) ACP and (c) ACZ. 
(see Figure 2). After activation and carbonization, there is the disappearance of some peaks in the FTIR spectra of the ACs and considerable decrease in the intensity of some peaks due to decomposition of cellulose, hemicellulose and lignin during the carbonization process [43]. However, there is an outstanding similarity in the spectra of both ACs. The band at $3421.6 \mathrm{~cm}^{-1}$ is attributed to the $\mathrm{O}-\mathrm{H}$ bond stretching vibration of absorbed water molecules [2]. The weak bands at 2923.6 and $2853.4 \mathrm{~cm}^{-1}$ indicate the $\mathrm{C}-\mathrm{H}$ stretching vibration of methyl and methylene group(s) [31] [43], while the two bands appearing at 1743.9 and $1701.0 \mathrm{~cm}^{-1}$ are attributed to the carbonyl group $(\mathrm{C}=\mathrm{O})$ of esters and carboxylic acid respectively [12]. The presence of $\mathrm{C}=\mathrm{C}$ of aromatic ring stretching vibration is recognized by the band observed at $1541.4 \mathrm{~cm}^{-1}$. The bands between 1400 and $1070.6 \mathrm{~cm}^{-1}$ signifies the presence of primary, secondary and ternary alcohol, phenol, ether and esters showing $\mathrm{C}-\mathrm{O}$ stretching and $\mathrm{O}-\mathrm{H}$ bond deformation vibration [31]. The peak at $673.6 \mathrm{~cm}^{-1}$ is indicates the out-of-plane $\mathrm{O}-\mathrm{H}$ vibration [15] [44].

\subsubsection{Elemental Analysis}

The results of the elemental analysis are provided in Table 6 . The carbon content of ACP and ACZ are significantly higher compared to that of the precursor (47.02\%). This could be due to an increase in the degree of aromaticity [15]. A decrease in the quantity of non-carbon species such as hydrogen, nitrogen and oxygen was observed, probably due to the release of moisture and volatile substances during carbonization process [17]. The difference in elemental analysis between ACP and ACZ could be explained by the relative low concentration of activating reagent and carbonization temperature involve in the preparation of ACP (Table 5).

\subsection{Adsorption Studies}

\subsubsection{Effect of Initial $\mathrm{pH}$}

An initial nitrate ions concentration of $50 \mathrm{mg} \cdot \mathrm{L}^{-1}$ was used to study the effect of $\mathrm{pH}$ on removal of nitrate ions in the range of $3-11$. The maximum quantity of nitrate ion removed occurred at $\mathrm{pH} 3$, and this amount decreases with increase in $\mathrm{pH}$ (Figure 8). The surface of $\mathrm{ACs}$ at low $\mathrm{pH}\left(\mathrm{pH}<\mathrm{pH}_{\mathrm{PZC}}\right.$ ) is predominantly positively charged as a result of the protonation of surface functional group(s), hence, more adsorption of nitrate ions by electrostatic attraction [42]. An increase in $\mathrm{pH}$ causes reduction of number of positive sites on the surface of the adsorbents, resulting to a reduction of adsorption capacity of adsorbent toward nitrate ions.

\subsubsection{Effect of Initial Concentration and Equilibrium Adsorption Isotherms}

The experimental data obtained was analyzed using Freundlich, Langmuir, D-K and Tempkin non-linear isotherm models (see Figure 9). The best fit of the experimental data was analyzed based on $R^{2}, R M S E$ and $\chi^{2}$. Hence, high $R^{2}$ value, low $R M S E$ and $\chi^{2}$ value established the best fitting adsorption isotherm [6]. 


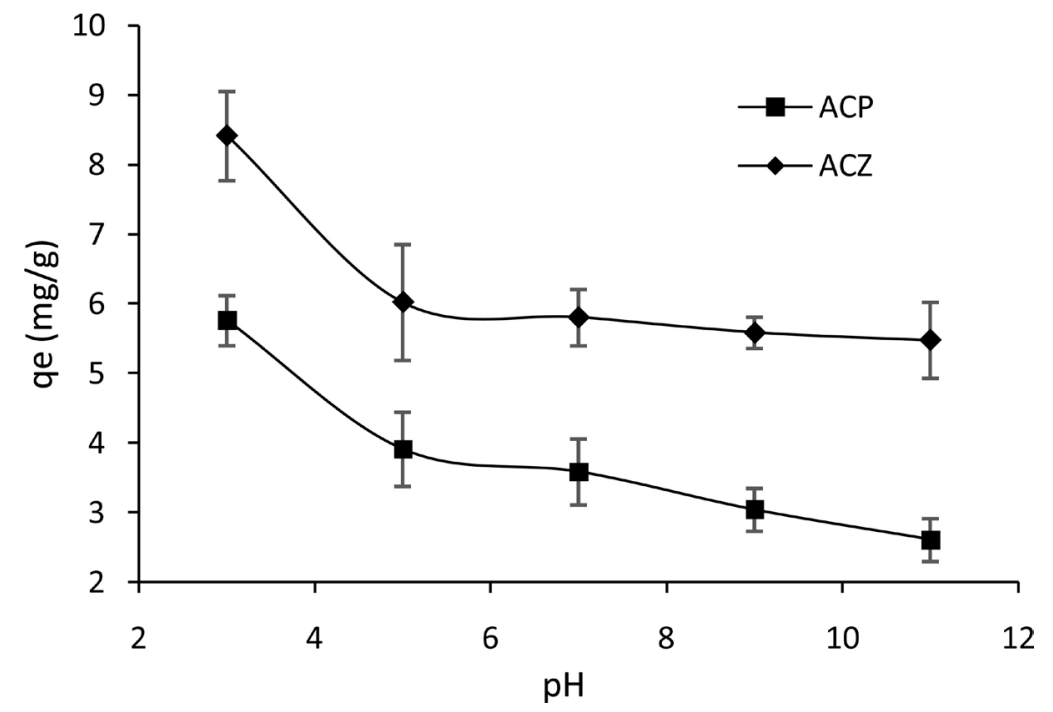

Figure 8. Effect of $\mathrm{pH}$ on the adsorption of $\mathrm{NO}_{3}^{-}$on ACP and ACZ.
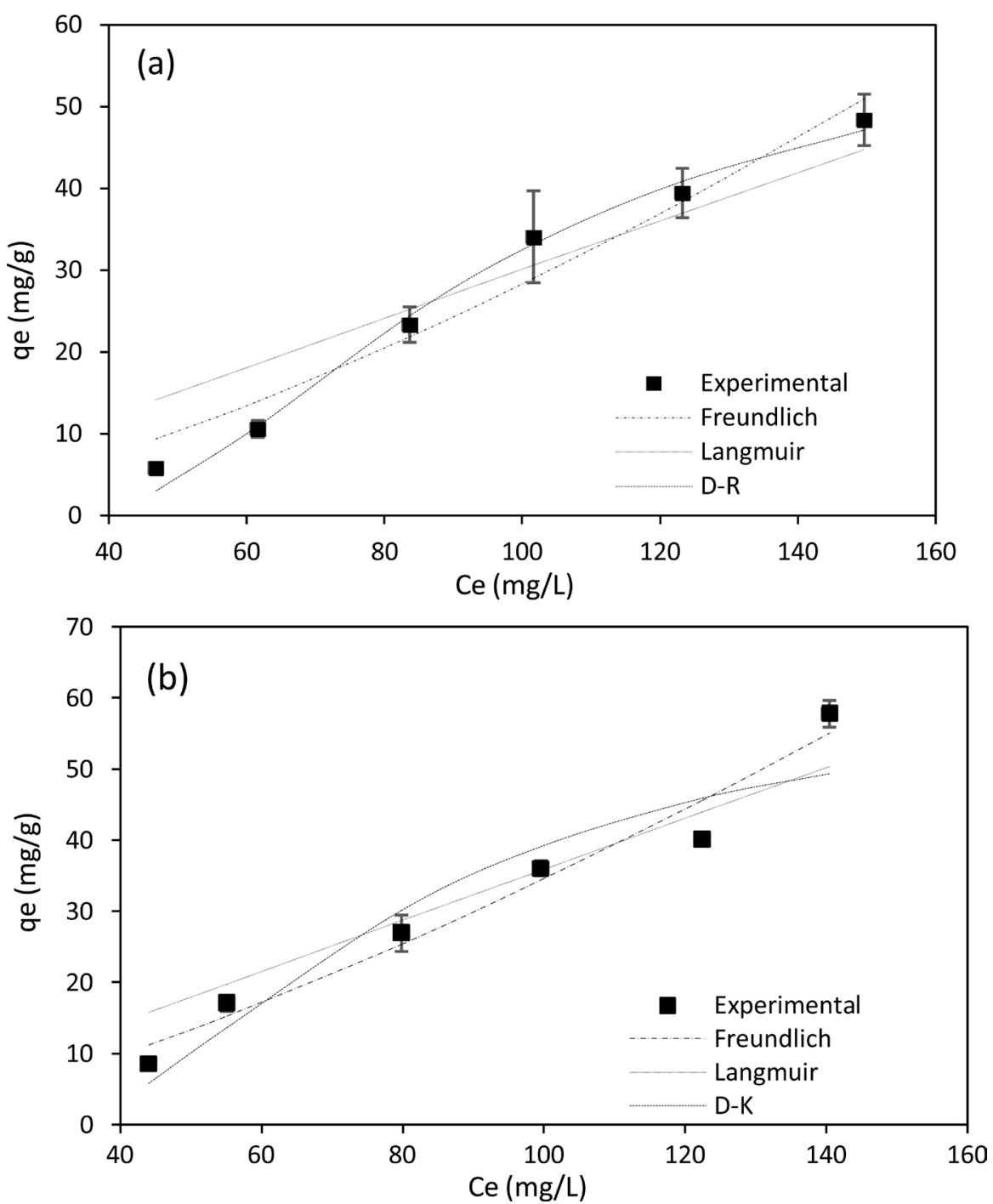

Figure 9. Adsorption isotherms of $\mathrm{NO}_{3}^{-}$on (a) ACP and (b) ACP. 
According to the presented result in Table 7, some discrepancies were observed in the Langmuir isotherm adsorption; lowest $R^{2}$ values, high $R M S E$ and $\chi^{2}$ values, unreasonably large value of $Q_{m}$ and insignificant $K_{L}$, rendering this model unsuitable to explain the adsorption phenomenon on ACP and ACZ. The Freundlich and D-K isotherms both fit the experimental data. In addition, the $n$ values obtained from the Freundlich adsorption isotherm model were 0.687 and 0.730 for ACP and ACZ, respectively. These values indicate that physisorption is dominant the process for both adsorbents [6]. The energy associated with the adsorption process can be calculated from the D-K model using the equation below

$$
E\left(\mathrm{~kJ} \cdot \mathrm{mol}^{-1}\right)=\frac{1}{\sqrt{2 k_{a d}}}
$$

From the model, if the magnitude of the energy $(E)$ lies in the range of $8-16$ $\mathrm{kJ} \cdot \mathrm{mol}^{-1}$, the sorption process is said to take place via ion exchange, whereas, if $E$ $<8 \mathrm{~kJ} \cdot \mathrm{mol}^{-1}$, the sorption process is said to be controlled by physical adsorption. The values of $E$ were found to be 0.021 and $0.027 \mathrm{~kJ} \cdot \mathrm{mol}^{-1}$ for ACP and ACZ, respectively, implying physical adsorption is dominant [2].

\subsubsection{Effect of Contact Time and Kinetic Studies}

The adsorption process was analyzed using three kinetic models, pseudo-first-order, pseudo-second-order and intraparticle diffusion kinetic model.

Table 7. Adsorption isotherm parameters for the adsorption of $\mathrm{NO}_{3}^{-}$on ACP and ACZ.

\begin{tabular}{|c|c|c|c|}
\hline \multirow{2}{*}{ Models } & \multirow{2}{*}{ Parameters } & \multicolumn{2}{|c|}{ Adsorbents } \\
\hline & & $\mathrm{ACP}$ & ACZ \\
\hline \multirow[t]{5}{*}{ Freundlich } & $K_{F}$ & 0.035 & 0.063 \\
\hline & $1 / n$ & 1.455 & 1.369 \\
\hline & $R^{2}$ & 0.957 & 0.965 \\
\hline & $R M S E$ & 3.874 & 3.653 \\
\hline & $x^{2}$ & 3.355 & 1.815 \\
\hline \multirow[t]{5}{*}{ Langmuir } & $q_{m}$ & 2752.29 & $236,754.9$ \\
\hline & $K_{L}$ & $10.6 \times 10^{-6}$ & $1.52 \times 10^{-6}$ \\
\hline & $R^{2}$ & 0.878 & 0.915 \\
\hline & $R M S E$ & 6.508 & 5.733 \\
\hline & $x^{2}$ & 9.422 & 5.170 \\
\hline \multirow[t]{6}{*}{$\mathrm{D}-\mathrm{K}$} & $q_{s}$ & 63.772 & 62.632 \\
\hline & $k_{a d}$ & $10.9 \times 10^{-4}$ & $7.60 \times 10^{-4}$ \\
\hline & $E$ & 21.391 & 25.691 \\
\hline & $R^{2}$ & 0.991 & 0.907 \\
\hline & $R M S E$ & 1.809 & 5.975 \\
\hline & $x^{2}$ & 2.574 & 4.932 \\
\hline
\end{tabular}


From Figure 10 the amount of nitrate ions adsorption on ACP and ACZ increases rapidly in first 10 minutes. This fast kinetics of adsorption may be due to the availability of large number of active sites on the adsorbent. Hence, equilibrium is rapidly achieved for both ACP and ACZ after $20 \mathrm{~min}$, as compare to chitosan hydrogel requiring $10 \mathrm{~h}$ [7], and activated carbon magnetic nanoparticles $1 \mathrm{~h} \mathrm{[5].}$

The pseudo-first-order kinetic model has a high $R^{2}$ value and low $R M S E$ and $\chi^{2}$ values among all models as shown in Table 8 . This implies that the pseudo-first-order kinetic model best describes the adsorption of the nitrate ions on $\mathrm{ACP}$ and ACZ. In addition, there was no significant variation between the experimental and calculated values of the quantity adsorbed $\left(q_{e}\right)$ of the pseudo-first-order kinetic model for both adsorbents. A similar observation was reported by Afkhami et al. [45] for adsorption of nitrate ions on acid modified carbon cloth. The low $R^{2}$ value and high values of $R M S E$ and $\chi^{2}$ obtained from the intraparticle diffusion kinetic model reveals that the pore diffusion is not the
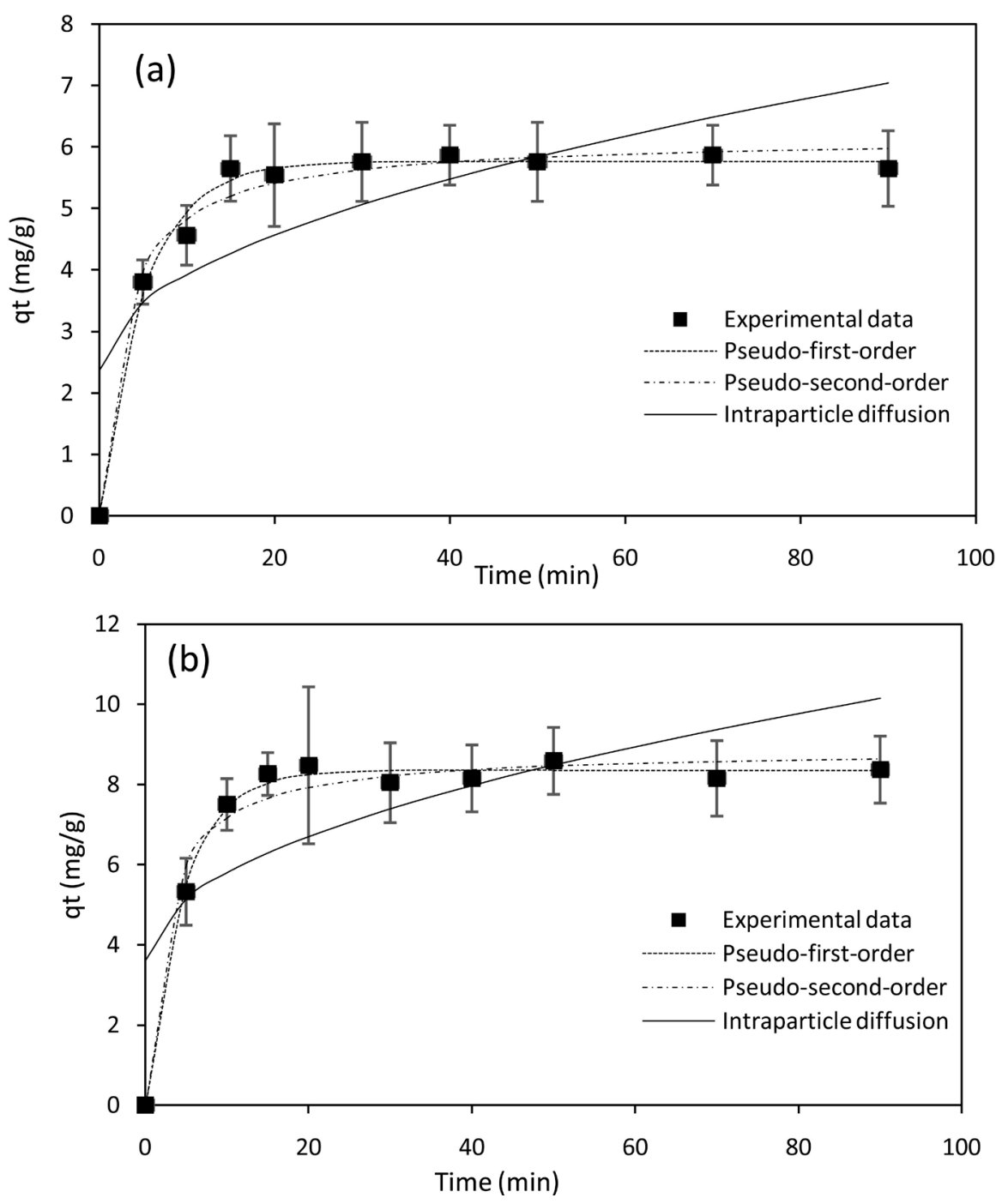

Figure 10. Effect of contact time on adsorption of $\mathrm{NO}_{3}^{-}$by (a) ACP and (b) ACZ. 
Table 8. Kinetics constants for the adsorption of $\mathrm{NO}_{3}^{-}$on ACP and ACZ.

\begin{tabular}{|c|c|c|c|}
\hline \multirow{2}{*}{ Models } & \multirow{2}{*}{ Parameters } & \multicolumn{2}{|c|}{ Adsorbents } \\
\hline & & $\mathrm{ACP}$ & $\mathrm{ACZ}$ \\
\hline \multirow[t]{6}{*}{ Pseudo-first-order } & $q_{e}(\exp )$ & 5.65 & 8.26 \\
\hline & $q_{e}($ pre $)$ & 5.766 & 8.352 \\
\hline & $k_{1}$ & 0.194 & 0.216 \\
\hline & $R^{2}$ & 0.991 & 0.994 \\
\hline & $R M S E$ & 0.185 & 0.219 \\
\hline & $x^{2}$ & 0.057 & 0.049 \\
\hline \multirow[t]{5}{*}{ Pseudo-second-order } & $q_{e}($ pre $)$ & 6.160 & 8.859 \\
\hline & $K_{2}$ & 0.058 & 0.038 \\
\hline & $R^{2}$ & 0.985 & 0.985 \\
\hline & $R M S E$ & 0.238 & 0.602 \\
\hline & $x^{2}$ & 0.086 & 0.208 \\
\hline \multirow[t]{5}{*}{ Intraparticle diffusion } & $K_{i p}$ & 0.493 & 0.688 \\
\hline & $C_{i}$ & 2.361 & 3.614 \\
\hline & $R^{2}$ & 0.851 & 0.819 \\
\hline & $R M S E$ & 2.911 & 1.879 \\
\hline & $x^{2}$ & 1.255 & 2.146 \\
\hline
\end{tabular}

rate-controlling step. In addition, the value of $C_{i} \neq 0$, suggest the adsorption is a complex process and involve more than one diffusive resistance process [5].

\section{Conclusion}

In the present study, Box-Behnken design was used to optimize the preparation conditions of ACs from Egusi seed shells (Cucumeropsis mannii) by chemical activation using two activating agents $\left(\mathrm{H}_{3} \mathrm{PO}_{4}\right.$ and $\left.\mathrm{ZnCl}_{2}\right)$. The ability of the optimized ACs (ACP and ACZ) towards nitrate ions removal was investigated. During optimization, the residence time for maximal responses (IN, MBN, and obtained yield) was 30 minutes for both ACP and ACZ. The concentration of $\mathrm{H}_{3} \mathrm{PO}_{4}$ and $\mathrm{ZnCl}_{2}$ and the carbonization temperature was $7 \mathrm{M}$ at $633^{\circ} \mathrm{C}$ and $10 \mathrm{M}$ at $698^{\circ} \mathrm{C}$ for $\mathrm{ACP}$ and $\mathrm{ACZ}$ respectively. $\mathrm{ACP}$ and $\mathrm{ACZ}$ were found to be microporous having surface areas of $1053.91 \mathrm{~m}^{2} \cdot \mathrm{g}^{-1}$ and $1009.89 \mathrm{~m}^{2} \cdot \mathrm{g}^{-1}$ respectively, obtained from BET analysis. FTIR showed that both ACs have approximately same surface chemistry. AFM images show the presence of well-developed pores and cavities on the surface of ACP and ACZ, which were absent in the precursor material. Maximum adsorption occurs at $\mathrm{pH} 3$ and the adsorption equilibrium was reached after 20 minutes for both ACs. ACZ showed a better adsorption capacity of nitrate ion as compared to ACP. The equilibrium and kinetic studies reveal that physical interaction exhibits between adsorbent and adsorbate. This study demonstrates the potential of Egusi seed shell as a good precursor for the 
preparation of activated carbons having large surface areas, and the ability of these ACs to be used as adsorbents for the removal of nitrate ions from wastewater.

\section{Acknowledgements}

The authors would like to thank The Word Academy of Sciences (TWAS) and International Center for Chemical \& Biological Sciences (ICCBS) for financial support of this study under ICCBS-TWAS Postgraduate Fellowship. The authors also thank all the members of the research group "Adsorption and Surface" of Applied Physical and Analytical chemistry laboratory of University of Yaoundé I.

\section{Conflicts of Interest}

The authors declare no conflict of interest.

\section{References}

[1] Loganathan, P., Vigneswaran, S. and Kandasamy, J. (2013) Enhanced Removal of Nitrate from Water Using Surface Modification of Adsorbents-A Review. Journal of Environmental Management, 131, 363-374. https://doi.org/10.1016/i.jenvman.2013.09.034

[2] Mehrabi, N., Soleimani, M., Yeganeh, M.M and Sharififard, H. (2015) Parameter Optimization for Nitrate Removal from Water Using Activated Carbon and Composite of Activated Carbon and $\mathrm{Fe}_{2} \mathrm{O}_{3}$ Nanoparticles. RSC Advances, 5, 51470-51482. https://doi.org/10.1039/C5RA03920G

[3] Nunell, G., Fernandez, M., Bonelli, P. and Cukierman, A. (2015) Nitrate Uptake Improvement by Modified Activated Carbons Developed from Two Species of Pine Cones. Journal of Colloid and Interface Science, 440, 102-108. https://doi.org/10.1016/j.jcis.2014.10.058

[4] WHO (2011) Guidelines for Drinking-Water Quality. 4th Edition, World Health Organisation, Geneva.

[5] Rezaei, R., Dehghanifard, E., Mohseni-Bandpi, A., Rezaei, L., Esrafili, A., Kakavandi, B. and Azari, B. (2016) Nitrate Adsorption by Synthetic Activated Carbon Magnetic Nanoparticles: Kinetics, Isotherms and Thermodynamic Studies. Desalination and Water Treatment, 57, 16445-16455. https://doi.org/10.1080/19443994.2015.1079251

[6] Kim, J.Y., Balathanigaimani, M. and Moon, H. (2015) Adsorptive Removal of Nitrate and Phosphate Using MCM-48, SBA-15, Chitosan, and Volcanic Pumice. Water, Air, \& Soil Pollution, 226, 431. https://doi.org/10.1007/s11270-015-2692-z

[7] Chatterjee, S. and Woo, S.H. (2009) The Removal of Nitrate from Aqueous Solutions by Chitosan Hydrogel Beads. Journal of Hazardous Materials, 164, 1012-1018. https://doi.org/10.1016/j.jhazmat.2008.09.001

[8] Ahmad, A., Hameed, B. and Ahmad, A. (2009) Removal of Disperse Dye from Aqueous Solution Using Waste-Derived Activated Carbon: Optimization Study. Journal of Hazardous Materials, 170, 612-619. https://doi.org/10.1016/j.jhazmat.2009.05.021

[9] Tan, I., Ahmad, A. and Hameed, B. (2008) Optimization of Preparation Conditions for Activated Carbons from Coconut Husk Using Response Surface Methodology. 
Chemical Engineering Journal, 137, 462-470.

https://doi.org/10.1016/j.cej.2007.04.031

[10] Tounsadi, H., Khalidi, A., Abdennouri, M. and Barka, N. (2016) Activated Carbon from Diplotaxis Harra Biomass: Optimization of Preparation Conditions and Heavy Metal Removal. Journal of the Taiwan Institute of Chemical Engineers, 59, 348-358. https://doi.org/10.1016/j.jtice.2015.08.014

[11] Yahya, M.A., Al-Qodah, Z. and Ngah, C.Z. (2015) Agricultural Bio-Waste Materials as Potential Sustainable Precursors Used for Activated Carbon Production: A Review. Renewable and Sustainable Energy Reviews, 46, 218-235. https://doi.org/10.1016/j.rser.2015.02.051

[12] Danish, M., Hashim, R., Ibrahim, M.N.M. and Sulaiman, O. (2014) Optimized Preparation for Large Surface Area Activated Carbon from Date (Phoenix dactylifera L.) Stone Biomass. Biomass and Bioenergy, 61, 167-178. https://doi.org/10.1016/j.biombioe.2013.12.008

[13] Kouotou, D., Manga, H.N., Baçaoui, A., Yaacoubi, A. and Mbadcam, J.K. (2012) Optimization of Activated Carbons Prepared by and Steam Activation of Oil Palm Shells. Journal of Chemistry, 2013, 10.

[14] dos Reis, G.S., Wilhelm, M., de Almeida Silva, T.C., Rezwan, K., Sampaio, C.H., Lima, E.C. and Ulson de Souza, S.M.A.G. (2016) The Use of Design of Experiments for the Evaluation of the Production of Surface Rich Activated Carbon from Sewage Sludge via Microwave and Conventional Pyrolysis. Applied Thermal Engineering, 93, 590-597. https://doi.org/10.1016/j.applthermaleng.2015.09.035

[15] Kumar, A. and Jena, H.M. (2016) Preparation and Characterization of High Surface Area Activated Carbon from Fox Nut (Euryale ferox) Shell by Chemical Activation with $\mathrm{H}_{3} \mathrm{PO}_{4}$. Results in Physics, 6, 651-658. https://doi.org/10.1016/j.rinp.2016.09.012

[16] Ndi, N.J. and Ketcha, M.J. (2013) The Adsorption Efficiency of Chemically Prepared Activated Carbon from Cola Nut Shells by on Methylene Blue. Journal of Chemistry, 2013, Article ID: 469170.

[17] Angin, D. (2014) Production and Characterization of Activated Carbon from Sour Cherry Stones by Zinc Chloride. Fuel, 115, 804-811.

https://doi.org/10.1016/j.fuel.2013.04.060

[18] Sayğılı, H. and Güzel, F. (2016) High Surface Area Mesoporous Activated Carbon from Tomato Processing Solid Waste by Zinc Chloride Activation: Process Optimization, Characterization and Dyes Adsorption. Journal of Cleaner Production, 113, 995-1004. https://doi.org/10.1016/j.jclepro.2015.12.055

[19] Gao, Y., Xu, S., Yue, Q., Wu, Y. and Gao, B. (2016) Chemical Preparation of Crab Shell-Based Activated Carbon with Superior Adsorption Performance for Dye Removal from Wastewater. Journal of the Taiwan Institute of Chemical Engineers, 61, 327-335. https://doi.org/10.1016/j.jtice.2015.12.023

[20] González, P., Hernández-Quiroz, T. and García-González, L. (2014) The Use of Experimental Design and Response Surface Methodologies for the Synthesis of Chemically Activated Carbons Produced from Bamboo. Fuel Processing Technology, 127, 133-139. https://doi.org/10.1016/j.fuproc.2014.05.035

[21] Mohammed, J., Nasri, N.S., Zaini, M.A.A., Hamza, U.D. and Ani, F.N. (2015) Adsorption of Benzene and Toluene onto $\mathrm{KOH}$ Activated Coconut Shell Based Carbon Treated with NH3. International Biodeterioration \& Biodegradation, 102, 245-255. https://doi.org/10.1016/j.ibiod.2015.02.012

[22] Aber, S., Khataee, A. and Sheydaei, M. (2009) Optimization of Activated Carbon 
Fiber Preparation from Kenaf Using $\mathrm{K}_{2} \mathrm{HPO}_{4}$ as Chemical Activator for Adsorption of Phenolic Compounds. Bioresource Technology, 100, 6586-6591. https://doi.org/10.1016/j.biortech.2009.07.074

[23] Auta, M. and Hameed, B. (2011) Optimized Waste Tea Activated Carbon for Adsorption of Methylene Blue and Acid Blue 29 Dyes Using Response Surface Methodology. Chemical Engineering Journal, 175, 233-243. https://doi.org/10.1016/j.cej.2011.09.100

[24] Giwa, S., Abdullah, L.C. and Adam, N.M. (2010) Investigating "Egusi" (Citrullus colocynthis L.) Seed Oil as Potential Biodiesel Feedstock. Energies, 3, 607-618. https://doi.org/10.3390/en3040607

[25] Kortse, P.A. and Oladiran, A.J. (2012) The Quality of "Egusi-Itoo" Melon (Cucumeropsis Mannii Naudin.) Seed Harvested at Different Fruit Ages. International Journal of Scientific and Research Publications, 2, 1-5.

[26] Sadiq, M., Abubakar, M. and Yusuf, T. (2013) Economies of Scale and Cost Efficiency in Small Scale Egusi Melon Production in Bida Local Government Area of Niger State, Nigeria. Journal of Agriculture and Veterinary Science, 2, 92-97. https://doi.org/10.9790/2380-0269297

[27] Bezerra, M.A., Santelli, R.E., Oliveira, E.P., Villar, L.S. and Escaleira, L.A. (2008) Response Surface Methodology (RSM) as a Tool for Optimization in Analytical Chemistry. Talanta, 76, 965-977. https://doi.org/10.1016/j.talanta.2008.05.019

[28] Sugashini, S. and Begum, K.M.S. (2013) Optimization Using Central Composite Design (CCD) for the Biosorption of $\mathrm{Cr}(\mathrm{VI})$ Ions by Cross Linked Chitosan Carbonized Rice Husk (CCACR). Clean Technologies and Environmental Policy, 15, 293-302. https://doi.org/10.1007/s10098-012-0512-3

[29] Ahmad, M.A. and Alrozi, R. (2010) Optimization of Preparation Conditions for Mangosteen Peel-Based Activated Carbons for the Removal of Remazol Brilliant Blue R Using Response Surface Methodology. Chemical Engineering Journal, 165, 883-890. https://doi.org/10.1016/j.cej.2010.10.049

[30] Zhang, Z. and Zheng, H. (2009) Optimization for Decolorization of Azo Dye Acid Green 20 by Ultrasound and $\mathrm{H}_{2} \mathrm{O}_{2}$ Using Response Surface Methodology. Journal of Hazardous Materials, 172, 1388-1393. https://doi.org/10.1016/j.jhazmat.2009.07.146

[31] Demiral, İ., Şamdan, A.C. and Demiral, H. (2016) Production and Characterization of Activated Carbons from Pumpkin Seed Shell by Chemical Activation with $\mathrm{ZnCl}_{2}$. Desalination and Water Treatment, 57, 2446-2454. https://doi.org/10.1080/19443994.2015.1027276

[32] Baccar, R., Bouzid, J., Feki, M. and Montiel, A. (2009) Preparation of Activated Carbon from Tunisian Olive-Waste Cakes and Its Application for Adsorption of Heavy Metal Ions. Journal of Hazardous Materials, 162, 1522-1529.

https://doi.org/10.1016/j.jhazmat.2008.06.041

[33] Qiu, P., Cui, M., Kang, K., Park, B., Son, Y., Khim, E., Jang, M. and Khim, J. (2014) Application of Box-Behnken Design with Response Surface Methodology for Modeling and Optimizing Ultrasonic Oxidation of Arsenite with $\mathrm{H}_{2} \mathrm{O}_{2}$. Central European Journal of Chemistry, 2, 164-172. https://doi.org/10.2478/s11532-013-0360-y

[34] Yin, G. and Dang, Y. (2008) Optimization of Extraction Technology of the Lycium barbarum Polysaccharides by Box-Behnken Statistical Design. Carbohydrate Polymers, 74, 603-610. https://doi.org/10.1016/j.carbpol.2008.04.025

[35] Aslan, N. and Cebeci, Y. (2007) Application of Box-Behnken Design and Response Surface Methodology for Modeling of Some Turkish Coals. Fuel, 86, 90-97.

https://doi.org/10.1016/j.fuel.2006.06.010 
[36] Yetilmezsoy, K., Demirel, S. and Vanderbei, R.J. (2009) Response Surface Modeling of $\mathrm{Pb}$ (II) Removal from Aqueous Solution by Pistacia vera L.: Box-Behnken Experimental Design. Journal of Hazardous Materials, 171, 551-562. https://doi.org/10.1016/j.jhazmat.2009.06.035

[37] Kyzas, G.Z., Deliyanni, E.A. and Matis, K.A. (2016) Activated Carbons Produced by Pyrolysis of Waste Potato Peels: Cobalt Ions Removal by Adsorption. Colloids and Surfaces A: Physicochemical and Engineering Aspects, 490, 74-83. https://doi.org/10.1016/j.colsurfa.2015.11.038

[38] Cataldo, D., Maroon, M., Schrader, L. and Youngs, V. (1975) Rapid Colorimetric Determination of Nitrate in Plant Tissue by Nitration of Salicylic Acid. Communications in Soil Science and Plant Analysis, 6, 71-80. https://doi.org/10.1080/00103627509366547

[39] Zhu, G.-Z., Deng, X.-L., Hou, M., Sun, K., Zhang, Y.-P., Li, P. and Lian, F.-M. (2016) Comparative Study on Characterization and Adsorption Properties of Activated Carbons by Phosphoric Acid Activation from Corncob and Its Acid and Alkaline Hydrolysis Residues. Fuel Processing Technology, 144, 255-261. https://doi.org/10.1016/j.fuproc.2016.01.007

[40] Joshi, R.R. (2016) Optimization of Conditions for the Preparation of Activated Carbon from Lapsi (Choerospondias axillaris) Seed Stone Using $\mathrm{ZnCl}_{2}$. Journal of the Institute of Engineering, 11, 128-139. https://doi.org/10.3126/jie.v11i1.14707

[41] Deng, H., Zhang, G., Xu, X., Tao, G. and Dai, J. (2010) Optimization of Preparation of Activated Carbon from Cotton Stalk by Microwave Assisted Phosphoric Acid-Chemical Activation. Journal of Hazardous Materials, 182, 217-224. https://doi.org/10.1016/j.jhazmat.2010.06.018

[42] Demiral, H. and Gündüzoğlu, G. (2010) Removal of Nitrate from Aqueous Solutions by Activated Carbon Prepared from Sugar Beet Bagasse. Bioresource Technology, 101, 1675-1680. https://doi.org/10.1016/j.biortech.2009.09.087

[43] Ozdemir, I., Şahin, M., Orhan, R. and Erdem, M. (2014) Preparation and Characterization of Activated Carbon from Grape Stalk by Zinc Chloride Activation. Fuel Processing Technology, 125, 200-206. https://doi.org/10.1016/j.fuproc.2014.04.002

[44] Gao, Q., Liu, H., Cheng, C., Li, K., Zhang, J. and Li, Y. (2013) Preparation and Characterization of Activated Carbon from Wool Waste and the Comparison of Muffle Furnace and Microwave Heating Methods. Powder Technology, 249, 234-240. https://doi.org/10.1016/j.powtec.2013.08.029

[45] Afkhami, A., Madrakian, T. and Karimi, Z. (2007) The Effect of Acid Treatment of Carbon Cloth on the Adsorption of Nitrite and Nitrate Ions. Journal of Hazardous Materials, 144, 427-431. https://doi.org/10.1016/j.jhazmat.2006.10.062 